\title{
Lugares de memoria, lugares de silencio: la esclavitud atlántica en museos españoles y cubanos desde una perspectiva comparada internacional
}

\section{Sites of memory, sites of sillence: Atlantic Slavery in Spanish and Cubans Museums from an international comparative perspective ${ }^{1}$}

\author{
Ulrike Schmieder ${ }^{2}$ \\ Leibniz Universität Hannover, Alemania \\ (D) https://orcid.org/0000-0003-3380-0744
}

Resumen: El artículo hace referencia a los resultados de un proyecto sobre memorias de la esclavitud atlántica. Compara los museos analizados en España y Cuba con respecto a la visualización y los discursos explicativos sobre el pasado esclavista, la imagen presentada de los esclavistas y los esclavizados (Museo de América en Madrid, Museo de Historia de Cataluña, Museo Marítimo, ambos en Barcelona; la Casa de África en La Habana, el Museo de la Ruta del Esclavo en Matanzas, la Sala Museo en Álava/Méjico) con museos del Reino Unido y Francia. El análisis de la museología fue acompañado de entrevistas con actores de la memoria. El estudio constata la falta de voz de los esclavizados en todos los museos españoles y cubanos excepto en el pequeño museo local de Álava/Méjico. En los museos españoles persisten imágenes visualizadas y conceptos verbales racistas sobre los esclavizados, que son mostrados como mercancías y seres humanos inferiores, y no como rebeldes y agentes de su propia historia. Además, los perpetradores y beneficiarios del tráfico de africanos y de la esclavitud no aparecen en la museología: la esclavización se presenta como un acontecimiento natural. El texto argumenta sobre las posibles causas de esta diferencia frente a los museos ingleses y franceses, en los que las exposiciones hacen referencia también a la resistencia de los esclavizados y en algunos casos citan fuentes que reflejan su propia perspectiva.

Palabras claves: Memoria; museo; esclavitud; Cuba; España.

Abstract: The article refers to the results of a project on memories of Atlantic slavery. It compares the analyzed museums in Spain and Cuba with respect to the visualization and explanatory discourses on the slaver past, the image presented of slaveholders and the enslaved (Museo de América in Madrid, Museo de Historia de Cataluña, Museo Marítimo, both in Barcelona; Casa de África in Havana, Museo de la Ruta del Esclavo in Matanzas, Sala Museo in Álava/ Méjico) with museums in the United Kingdom and France. The museology analysis was accompanied by interviews with actors of memory. The study found a lack of voice for the enslaved in all Spanish and Cuban museums except in the small local museum in Álava/ Méjico. In the Spanish museums, racist visualization and verbal concepts persist about the enslaved, who are shown as commodities and inferior human beings and not as rebels and agents of their history. Moreover, the perpetrators and beneficiaries of African trafficking and slavery do not appear in the museology;

Recibido: 01/07/2020 | Aceptado: 02/12/2020| Disponible en línea: 20/01/2021

Como citar este artículo: Schmieder, U. (2021). Lugares de memoria, lugares de silencio: la esclavitud atlántica en museos españoles y cubanos desde una perspectiva comparada internacional. Jangwa Pana 20(1), 52-80. doi: https://doi.org/10.21676/16574923.3913

\footnotetext{
1 Este artículo es uno de los resultados del proyecto de investigación financiado por la Deutsche Forschungsgemeinschaft (DFG), SCHM 1050/5-1.

${ }^{2}$ Correo electrónico: schmieder@hist.uni-hannover.de
} 
perpetrators and beneficiaries of African trafficking and slavery do not appear in the museology; enslavement is presented as a natural event. The text discusses the possible causes of this difference compared to English and French museums, where exhibitions also refer to the resistance of the enslaved and in some cases cite sources that reflect their perspectives.

Keywords: Cuba; Memory; Museum; Slavery; Spain.

\section{Introducción}

En este artículo se presenta una parte de los resultados de nuestra investigación sobre los sitios de memoria de la esclavitud en Francia y España, Martinica y Cuba. Dichos resultados derivan de un proyecto sobre esclavitud y postemancipación en Martinica y en Cuba. Resultó que en muchos lugares conectados históricamente con esta historia reina el silencio o se narran historias totalmente distorsionadas sobre el esclavismo y sus consecuencias. No se refleja en estos espacios el debate internacional sobre las reparaciones materiales y simbólicas iniciado con la Ruta del Esclavo de la UNESCO (1994) y la Primera Conferencia Mundial contra el Racismo en Durban (2001), así como con la lucha contra la discriminación de los afrodescendientes y el legado de la esclavitud en el año 2011, y el decenio internacional para los afrodescendientes (2015-2024) de las Naciones Unidas.

Como objeto de estudio fueron escogidas las mencionadas islas, que fueron colonias de las antiguas potencias de Francia y España, y cuya historia es conocida por la autora de esta investigación. Referirse a estas regiones es muy importante porque la historiografía sobre las memorias de la esclavitud se concentra sobre todo en el mundo anglosajón, el Reino Unido, el Caribe inglés (Kowalewski, 2006; Rice, 2010; Smith, Cubitt, Wilson y Fouseki, 2011; Cummins, 2013) y los Estados Unidos (Eichstedt y Small, 2002; Burns, 2013; Gallas y DeWolf Perry, 2015). Hay más historiografía producida sobre Francia y el Caribe francés (Reinhardt, 2006; Chivallon, 2012; Michel, 2015; Frith y Hodgson, 2015), que sobre España (Surwillo, 2014). En el caso de Cuba, los estudios críticos sobre memorias y contramemorias de la esclavitud - incluyendo los silencios - son escasos

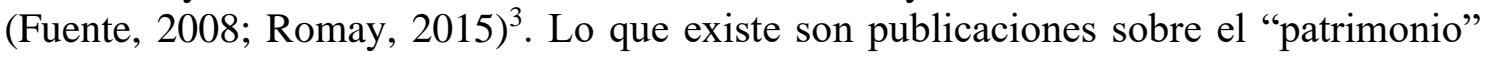
(azucarero, cafetalero, entre otros) que hacen referencia al legado técnico y/o arquitectónico de haciendas y centrales, separando la historia y la memoria de la producción, de la de los primeros productores: los africanos esclavizados (Zanetti y García, 1987; Santamaría et al., 2019).

Asimismo, hay pocos estudios comparativos (Wood, 2000; Hourcade, 2014; Dinter, 2018) y ninguno incluye al imperio español. No debe confundirse la historiografía sobre la memoria de la esclavitud con los estudios sobre la historia de la esclavitud, que se discutirán en los siguientes apartados. Estos últimos estudios han experimentado un auge en todos los países que son objeto de esta investigación, a pesar de que los resultados se hayan ido incluyendo a ritmos muy diferentes en las explicaciones museológicas.

La investigación se enfoca en París y en Madrid, capitales y antiguos centros de los imperios, lugares de decisión sobre la esclavitud y la abolición; lugares hacia donde se transferían los lucros de la esclavitud atlántica; centros de la diáspora africana y afrocaribeña; dos ciudades portuarias importantes en el tráfico de africanos como Nantes

\footnotetext{
${ }^{3}$ No puedo referirme aquí, además, a Brasil e Hispanoamérica. Sobre Colombia: Mosquera y Barcelos, 2007.
} 
y La Rochelle (puertos 1 y 2 de Francia en el siglo XVIII, y en el caso de Nantes hasta 1830), Cádiz y Barcelona (puertos número 1 y 2 de España en los siglos XVIII y XIX). Sobre el Caribe se estudian los casos de Fort-de-France (capital del Departamento ultramarino de Martinica), La Habana (capital de la República de Cuba) y, concretamente, sitios escogidos en cada isla donde se concentran los lugares de memorias, como los municipios Trois Ilets y Diamant en Martinica, Matanzas y su hinterland, y el Valle de los Ingenios, un valle con muchas plantaciones azucareras en la provincia de Sancti Spíritus. Este atrae a numerosos turistas que llegan para ver la restaurada ciudad colonial de Trinidad, patrimonio de la humanidad, y el ingenio Manaca, el más conocido del valle.

La noción "sitios de memoria" o "lugares de memoria" proviene del concepto de Pierre Nora "lieux de mémoire", lugares que conforman la identidad nacional francesa (a pesar de que Nora excluyó los territorios ultramarinos) (Nora, 1984-1992). Se trata de un concepto muy amplio, ya que para Nora no solamente los cementerios de soldados o la Tour Eiffel son espacios de memoria, sino que también incluye a personas (Jeanne d'Arc) o movimientos históricos (la Vendée). Este estudio se centra en los lugares físicos de memoria que han sido creados (museos, monumentos) y en los vestigios del pasado (la casa señorial, los barracones, la residencia de un comerciante de personas esclavizadas o de un hacendado esclavista en Europa, entre otros). Partimos de la idea de Nora de que un monumento no es per se un lugar de memoria (puede ser simplemente piedra), sino que se convierte en uno cuando allí comienzan a realizarse con regularidad ceremonias de conmemoración. De esta manera, el monumento Le cri, l'écrit en el Jardin du Luxembourg en Paris, el memorial para la abolición de esclavitud en Nantes, la estatua de la mujer esclavizada Modeste Testas en Burdeos, entre muchos otros, se convirtieron en "lieux de mémoire" cuando cada año el 10 de mayo, Día nacional de las memorias de la trata, la esclavitud y sus aboliciones, se conmemoró el pasado esclavista de Francia y el Presidente de la República, el Prefecto, el Alcalde, los diputados y los representantes de las asociaciones africanas y antillanas pronunciaron un discurso.

En paralelo a las fechas internacionales por la memoria de la esclavitud existen historias nacionales que marchan a otro ritmo. En el caso de Francia, el 150 aniversario de la abolición de la esclavitud en el año 1998 constituyó un viraje en las políticas de memoria, porque los antillanos ya no aceptaban una memoria que recordase la abolición de la esclavitud como acto heroico de la nación francesa por los derechos humanos, negando el sufrimiento y la resistencia de los esclavizados y la explotación de sus descendientes en la época colonial. Esto llevó a la ley Taubira de 2001 (propuesta por la diputada afroguayanesa Christiane Taubira) que reconocía el tráfico de africanos y la esclavitud como crímenes contra la humanidad, e incorporaba aspectos como el establecimiento de instituciones nacionales que coordinaran actividades de conmemoración, la introducción de días conmemorativos en el calendario nacional, la inclusión del tema en los currículos escolares $^{4}$ y la inauguración de monumentos. El Centre international de recherches sur les esclavages et post-esclavages (CIRESC, creado en 2005) fomenta la realización de

\footnotetext{
${ }^{4}$ Esto no fue un proceso que se desarrolló de forma lineal. En 2005, la ley Taubira chocó con la Ley Repatriés (promulgada durante la presidencia de Sarkozy) que obligó a los profesores a mostrar aprecio por el colonialismo francés en un párrafo borrado en 2006 (sobre este conflicto véase: Coquery-Vidrovitch, 2009, 110-132). A finales de 2016, la presidenta del Comité National de la Mémoire et Histoire FME, Myriam Cottias, defendió el mantenimiento del tema de la esclavitud atlántica en los currículos escolares (entrevista con su encargada de misiones, Florence Alexis, 28.5.2018) y, recientemente, la Fondation pour la Mémoire de l'esclavage criticó que el tema se está tratando de manera desigual en diferentes tipos de escuela, teniendo un papel menor las voces de los esclavizados y la revolución haitiana (FME, 2020).
} 
una serie de publicaciones sobre la esclavitud y sus memorias desde un enfoque centrado en la agencia histórica de los esclavizados ${ }^{5}$. En Gran Bretaña, en 2007, el bicentenario de la prohibición de la trata en el Reino Unido cambió significativamente. De una muchedumbre de exposiciones temporales se hicieron galerías permanentes en museos (la galería "Londres, azúcar y esclavitud" en el Docklands Museum, la galería atlántica del Museo Nacional Marítimo en Greenwich). El Museo Internacional de Esclavitud abrió sus puertas en Liverpool. En 2008, el comercio de africanos esclavizados se introdujo en los currículos escolares de educación secundaria en el Reino Unido, y los museos se convirtieron en espacios donde los alumnos podían adquirir conocimientos al respecto (Spalding, 2011) ${ }^{6}$.

Por el contrario, el bicentenario del fin del tráfico "legal" de africanos esclavizados desde puertos españoles hacia las Américas (2019) pasó desapercibido en España. El centenario de la abolición de la esclavitud en Cuba (1986) fue conmemorado mediante conferencias académicas y la inauguración de la Casa de África en La Habana.

Las memorias locales de la esclavitud pueden seguir otros calendarios. En Nantes, el debate comenzó en 1985 en ocasión del tricentenario del Code Noir y llegó a un primer punto de culminación en los años 1992-1994 con una gran exposición sobre el tema en el Castillo de la ciudad. Liverpool ya se había disculpado por su papel de liderazgo en la trata de africanos en 1999, gracias a la lucha del diputado del Labour Party Bernie Grant y de la activista local Dorothy Kuya, ambos integrantes del African Reparation Movement. En Martinica, la fecha del 22 de mayo, día en el que los esclavizados se rebelaron en 1848 anticipando la emancipación anunciada por parte del gobierno republicano (Pago, 2006) es un día conmemorativo feriado desde 1983. Finalmente, movimientos internacionales han tenido repercusiones locales, como el derrumbe de la estatua del traficante de africanos Edward Colston en Bristol, Reino Unido, el 7 de junio de 2020, en el contexto de las manifestaciones antirracistas surgidas a raíz del asesinato racista del afroamericano George Floyd en Minneapolis, EE. UU, ocurrido el 25 mayo de 2020 .

A continuación, se emprenderá una lectura detallada (close reading) de los textos descriptivos y de las imágenes mostradas en algunos museos escogidos, comparándolos puntualmente con las narraciones en museos europeos de otros países. Se hará referencia al Museo de América en Madrid, al Museo de Historia de Cataluña y al Museo Marítimo en Barcelona para el caso de España, la Casa de África en La Habana, el Museo de la Ruta del Esclavo en Matanzas y la Sala Museo de la Central Azucarera en Méjico (Álava en el siglo XIX), dependencia del Museo Municipal de Colón, para Cuba. No se ha abierto ningún museo en Cádiz porque la ciudad niega rotundamente su pasado africano-

\footnotetext{
${ }^{5}$ https://esclavages.cnrs.fr/publications/collection-esclavages/ 20.11.2020.

${ }^{6}$ Actualmente ya no forma parte de los currículos escolares (Department of Education, History programmes of study: key stage 3. National curriculum in England: Britain's transatlantic slave trade: its effects and its eventual abolition appears as "non-statutory" in the compulsory teaching of "ideas, political power, industry and empire: Britain, 1745-1901"

(https://assets.publishing.service.gov.uk/government/uploads/system/uploads/attachment_data/file/23907 5/SECONDARY_national_curriculum_-_History.pdf, 24.11.2010). En 2020 ha surgido un movimiento por la introducción de una Black British History en los currículos escolares, incluyendo la historia anterior y posterior a la trata, con el objetivo de aprender sobre la historia africana al margen de la influencia colonial y esclavista. (https://www.change.org/p/secretary-of-state-for-education-make-black-british-historycompulsory-in-schools-71e42535-7049-472d-a095-cfebdf717db6, 24.11.2020).
} 
traficante/esclavista (Cozar y Rodrigo, 2018) y la presencia de africanos esclavizados en la ciudad (Morgado García, 2013) en el paisaje museológico. En el caso de Cuba se tratarán dos museos de varios lugares de memoria oficiales: uno que es parte de la Ruta del Esclavo y un sitio único, local, que representa la memoria "desde abajo" de los descendientes de los esclavizados.

\section{Materiales y métodos}

Los viajes de investigación a París y al este de Francia, Nantes y La Rochelle, Madrid, Cádiz y Barcelona, y a Cuba ya se hicieron. Se documentaron y analizaron los monumentos, así como todo lo referente a la imagen visual de los esclavistas, de los esclavizados, los barcos de la trata, las plantaciones, las visualizaciones simbólicas (por ejemplo, la imagen de cadenas rotas), entre otros.

¿Se intentan contrariar imágenes racistas de la época colonial? Siguiendo el close reading y el análisis de las explicaciones de los monumentos, además de los objetos en museos, estos pueden entrar en contradicción con las imágenes visuales. ¿Representa la narración de forma adecuada los hechos históricos siguiendo la tendencia historiográfica actual? ¿Se citan fuentes que reflejen los discursos de los esclavistas, las voces de los esclavizados o de terceros testigos como los viajeros? ¿Se intenta descolonizar el lenguaje explicativo? ¿Se habla de las condiciones de vida y trabajo de los esclavizados y su resistencia, o solamente sobre comercio y economía? ¿Se representa la esclavitud como un hecho que terminó con la emancipación o se muestra el trabajo forzoso postesclavista y los legados de la esclavitud bajo el racismo? Respecto a los monumentos, se estudia la ubicación de cada monumento o museo en el espacio público: ¿está en el centro de la ciudad o al margen?, ¿es fácil de encontrar?, ¿es grande o pequeño?

Por otro lado, se ha reconstruido la historia del entorno social del sitio de memoria: ¿quién estuvo a favor y quién estuvo en contra de establecer un monumento a los cimarrones, a un/a abolicionista, de abrir un museo sobre la esclavitud o de incluir el tráfico de personas esclavizadas en el museo municipal? ¿Con qué argumentos se justifica el 'sí' o el 'no' a un sitio de memoria? ¿Quién usa un museo o un monumento y para qué fin? ¿Continúan los debates polémicos en espacios como la prensa o las redes sociales? Durante el desarrollo de la investigación se han aplicado los métodos de la historia oral (entrevistas) y la observación participante en eventos de conmemoración? ${ }^{7}$.

En Europa, la autora entrevistó a historiadores activos en el campo de memoria histórica, que han organizado congresos académicos y eventos públicos para divulgar los conocimientos históricos entre un público más amplio. En Francia han sido cuestionados los miembros del Comité Nacional de Memoria e Historia de la Esclavitud y su institución sucesora, la Fundación Nacional para la Memoria de la Esclavitud, organismos que coordinan las conmemoraciones de la esclavitud, que producen material educativo y desarrollan las reacciones públicas. Directores, conservadores y guías de museos fueron nuestros interlocutores porque podían brindarnos información sobre la historia de un museo, los conceptos museológicos aplicados, el público y los socios de cooperación. También conversamos con artistas, activistas, miembros de asociaciones africanas/antillanas que representan la sociedad civil que rodea los sitios de memoria y actúan muchas veces como pressure groups para establecer y/o reformar museos. En el

\footnotetext{
${ }^{7}$ La autora participó p. ej. en ceremonias conmemorativas estatales y comunales: el 10 y 23 mayo de 2018 en París, y el 10 mayo de 2017 y 2019 en Burdeos.
} 
Caribe fueron entrevistadas personas de la misma categoría, además de representantes martiniqueses del movimiento por memoria y reparación de la esclavitud e intelectuales afrocubanos, algunos pertenecientes a instituciones para la promoción de la cultura afrocubana como el Comité Aponte, y otros no vinculados a estas instituciones, para compensar la escasa representación de los afrocubanos en las direcciones de museos y en la comunidad académica. Asimismo, la autora habló con los descendientes de los esclavizados en los lugares de memoria escogidos ${ }^{8}$. ¿Muestran interés por estos sitios y los visitan? En caso afirmativo, ¿cómo los evalúan? ¿Han sido preguntados por las memorias familiares de la esclavitud por parte de los museólogos? ¿Tienen alguna ventaja económica en las visitas turísticas a estos espacios?

\section{Análisis de los museos en España}

En Madrid, el museo por antonomasia en el que se podría esperar encontrar información detallada sobre la tercera raíz de las culturas latinoamericanas es el Museo de América ${ }^{9}$, gestionado por el Ministerio de Cultura y Deporte. La exposición permanente actual del museo, fundado en 1941, data de 1994. Es decir, fue instalada en la época postfranquista. Su enfoque antropológico se aleja de la glorificación de los conquistadores, pero no incorpora un análisis crítico del pasado colonial. El museo se concentra en gran medida en las culturas indígenas sin una reflexión profunda sobre lo que la conquista significó para ellas.

El comercio de africanos esclavizados está explicado en la vitrina "emigración africana" en la sección de "La realidad en América". El título evoca una llegada voluntaria y no aporta ninguna impresión de lo que significó el terrible viaje para los cautivos. Continúa: "Ya en 1501 hay noticias de la presencia de esclavos negros en la Española" ¿Cómo llegaron allí? ¿Cómo se convirtieron los africanos libres en esclavizados negros? El texto sugiere que el estatus natural, inherente al "negro", es el del esclavo. "El dramático descenso de la población nativa americana, diezmada por las enfermedades llevadas por los europeos (viruela, sarampión, gripe) y por el nuevo régimen de vida impuesto por los conquistadores, abrió las puertas al comercio negrero para proporcionar mano de obra a las explotaciones mineras y agropecuarias. Los esclavos negros procedían principalmente de la costa occidental de África, si bien la demanda creciente y el despoblamiento producido obligó a buscar nativos de otras regiones”. ¡Ay! Además de que a través de estas palabras nadie se podría imaginar el trabajo infernal en las minas y las plantaciones, es preciso cuestionar por qué el texto ni siquiera menciona los motivos por los cuales los europeos no hacían ellos mismos estos trabajos. ¿Dan por hecho los museólogos que los blancos constituyen la raza dominante que no se ensucia las manos? ¿"El comercio

\footnotetext{
${ }^{8} \mathrm{Ni}$ en Europa ni en el Caribe fue y es posible entrevistar exactamente a los mismos grupos de actores en el campo de memoria. En España no existen instituciones estatales explícitamente responsables de la conmemoración de la esclavitud, y el número de asociaciones de africanos y afroantillanos es más reducido que en Francia. Por otro lado, los sindicatos se suman al debate, lo cual no ocurre en Francia. En Martinica hay una diversidad de ONG que no existe en Cuba, y las políticas de memoria funcionan de una manera mucho más descentralizada: no hay nada comparable al Comité Aponte. Además, la accesibilidad de los interlocutores no depende de la voluntad de la investigadora. Puede ser que la directora de un museo no tenga tiempo o interés en hablar con la investigadora. La autora no ha tenido malas experiencias a la hora de hablar con personas posicionadas en un nivel más bajo de la jerarquía, porque aquellos que hacen el trabajo diario también pueden dar información relevante. En cuanto a las asociaciones, tienen normalmente muy pocos miembros activos y por eso no siempre están dispuestos a ser entrevistados. Generalmente, en la provincia es más fácil encontrar a interlocutores que en la capital.

${ }^{9}$ Visita el 6.9.2018.
} 
negrero" fue un acontecimiento natural que cayó del cielo y se autoorganizó? ¿No existían vendedores y compradores de los cautivos, comerciantes, capitanes, tripulaciones o consumidores de azúcar? La demanda creciente tampoco se explica en el texto. Constantemente se necesitaban más africanos en las Américas porque la tasa de mortalidad era a menudo mayor que la tasa de natalidad, y la plantación era un sistema aniquilador de seres humanos, por lo menos en el Caribe, Brasil y las plantaciones azucareras de los Estados Unidos (Bergad, 2007, 96-104).

En una vitrina se muestra una figura bieri (un ancestro en la cultura Fan en África Occidental), un collar de hierro, sandalias, un látigo y un machete. La grabación de voz relativa a la figura bieri explica la existencia de religiones de origen africano en las Américas. Sin embargo, no se menciona para qué servía el látigo. No aparece ninguna referencia a la resistencia de los esclavizados, ni tampoco se informa sobre los reinos de África, las grandes ciudades o las culturas y artes africanas.

Fuera de esta vitrina, africanos y afrodescendientes aparecen en estadísticas demográficas y en la pintura de casta racista (Katzew, 2004), sin contexto alguno. Así, el visitante observa, por ejemplo, en la pintura "De Español y Negra nace Mulata", ${ }^{10}$ cómo una mujer africana pega a su marido blanco y la hija de ambos trata de prevenirlo. El mensaje es que la mujer negra no es una verdadera mujer: suave, sumisa, obediente a su marido. En consecuencia, el matrimonio interétnico pone el orden social patas arriba. En ningún lugar se explica la política de la corona española a fines del siglo XVIII contra los "matrimonios desiguales", ${ }^{11}$ en los que eran vistos como un peligro para el orden colonial, basado en una jerarquía étnica-social que situaba a los africanos esclavizados en la posición más baja de todas.

Las entrevistas con una persona de alto rango del departamento colonial del Museo fueron las más complicadas de las más de cien entrevistas realizadas a ambos lados del Atlántico. Su perspectiva refleja ideas tales como dudar del hecho de que 'las Indias' fuesen colonias, que el museo de historia de América es fundamentalmente de arte y sus visitantes esperan ver solamente obras artísticas, y que el museo contiene objetos de culturas indígenas que coleccionaron como afición los españoles en América. Del mismo modo se considera que la carencia de fondos sobre África es debida a que España no tenía colonias africanas ${ }^{12}$ y que en África no se producían objetos de valor para su exposición. Así, la pintura de castas es percibida exclusivamente como arte: los pintores simplemente retrataron lo que veían a su alrededor, y en el caso concreto del cuadro "De Español y Negra nace Mulata”, su creador advertía de un 'falso matrimonio'. En el trascurso de las entrevistas realizadas no se observó ninguna reflexión crítica sobre los términos "raza" o "etnia" como construcciones jerárquicas y discriminatorias, y no como hechos biológicos. Tampoco se reflejó el debate sobre la devolución de los bienes expoliados a los colonizados, sino más bien una aversión explícita hacia las teorías críticas postcoloniales.

Sería deseable que en la próxima reforma del museo se incorporasen investigaciones más recientes sobre la esclavitud (Piqueras, 2012), sobre la agencia y resistencia de los esclavizados (Laviña y Ruiz-Penado, 2006, Belmonte 2011), sobre el tráfico de africanos,

\footnotetext{
${ }^{10}$ Andrés de Islas. México, 1774.

11 "Real Pragmática Sanción para evitar el abuso de contraer matrimonio", 1776, válido en América desde 1778.

${ }^{12}$ ¿Y Guinea Ecuatorial, colonia española 1778-1968?
} 
ya fuese el tráfico de los primeros siglos (Pérez García, 2018) o la trata ilegal del siglo XIX, así como la transferencia de lucros para la modernización de la metrópoli (Nerín, 2015; Rodrigo y Chaviano, 2017; Cozar y Rodrigo, 2018), además de la abundante historiografía cubana o hispanoamericana. En octubre de 2021 se inauguró la primera exposición sobre este tema en el Museo de América: "La esclavitud y el legado cultural de África en el Caribe" ${ }^{\prime 3}$.

El Museo de Historia de Cataluña, organismo fundado en 1996 y dependiente de la Generalitat de Cataluña, narra una historia que glorifica la nación catalana con el objetivo de identificarse con ella. En la galería sobre el siglo XIX, con un fuerte enfoque sobre el comercio, la industrialización y urbanización del país ${ }^{14}$ y el movimiento cultural del Renacimiento catalán, hay una vitrina sobre el comercio triangular en el Atlántico. Bajo un mapa que muestra las rutas del negocio se encuentran cajas que contienen las mercancías del comercio, tales como café, azúcar, arroz, sal, algodón, entre otros. Los esclavizados, una mercancía entre otras, se simbolizan mediante una cadena. El texto dice: “(...). Los barcos que hacen la ruta del Río de la Plata cargan tasajo (carne salada), que se vende en la isla de Cuba para alimentar a los esclavos. (...) Cuba suministra tabaco, azúcar, café y cacao". No se menciona que fueron "producidos por africanos esclavizados bajo el látigo, quienes morían pocos años después de su llegada". Continúa: "en el período legal de la venta de los esclavos (1789-1819), unas 146 embarcaciones catalanas introducen esclavos en Cuba lo que significa la llegada de unos 30.000 esclavos". Estas son, sin duda, las cifras de Fradera (1984, p. 124). La referencia a la "legalidad sugiere que había una trata clandestina, aunque no aparece mencionada en el museo. Durante el período ilegal (1820-1866) se transportaron muchos más esclavizados que con anterioridad, ${ }^{15}$ y los catalanes jugaron un papel muy importante en este tráfico ilícito (Fradera, 1984; Rodrigo, 2017; Zeuske, 2017). Tampoco hay ninguna referencia a la transferencia de beneficios para la urbanización e industrialización de Barcelona (Rodrigo, 2012).

Quienes desconocen esta historia, es decir, una parte importante de los españoles, dado que la esclavitud en Hispanoamérica no forma parte de los currículos escolares, no reciben en estos espacios información alguna sobre los horrores de la travesía, el durísimo trabajo en las plantaciones o la tortura. Tampoco se expone información sobre el cimarronaje y la rebeldía de los esclavizados. De nuevo, la esclavitud se adscribe a los africanos como si fuese un estatus natural. Este discurso no está descolonizado en ningún aspecto. En una conversación ${ }^{16}$ con la conservadora del museo, Teresa Rodon i Borras, y con el historiador asesor, Martín Iturralde Valls, se comentó que algunos visitantes ya habían criticado la representación de los esclavizados de la manera descrita. De acuerdo con la institución, se realizará una reforma de la galería sobre los siglos XIX y XX en los

\footnotetext{
${ }^{13}$ Curado por Consuelo Naranjo Orovio y Miguel Ángel Puig-Samper, del proyecto ConnecCaribbean (Connected Worlds: The Caribbean, Origin of Modern World, http://conneccaribbean.com/ 20.11.2020).

${ }^{14}$ Cita tabla 27 a: "En la formación de la industria catalana convergen un gran número de capitales. Algunos proceden de la compaginación de una primera actividad comercial. También son importantes los capitales repatriados de América. Pero la mayoría de las fábricas de vapor se constituye con capitales exiguos de ámbito familiar (...)".

${ }^{15}$ Borucki, Eltis y Wheat, 2015, 440: 563100 cautivos llegaron a las Américas bajo la bandera española entre 1821 y 1866 (133 600 entre 1789-1820). Eltis/ Felipe-González, 2020, 205: A Cuba llegaron 540818 africanos esclavizados directamente desde África entre 1821 y 1870 (247 443 entre 1791-1820).

${ }^{16}$ Entrevista 5.2.2020.
} 
próximos tres años, con el objetivo de fortalecer la historia sociocultural de las capas sociales más bajas.

Que se produzca un cambio sustancial dependerá de que el Museo se despida realmente de la narrativa nacionalista y admita el importante papel de Cataluña y de los comerciantes-industriales catalanes en la política imperial de la monarquía española. Los expertos en los temas sobre trata-esclavitud-colonialismo-transferencia de capitales hacia la metrópoli en las universidades barcelonesas ${ }^{17}$ comentaron al unísono que los museólogos del Museo de Historia nunca les han pedido consejo ni colaboración, contrariamente a los museólogos del Museo Marítimo.

El Museo Marítimo de Barcelona está administrado por un consorcio de la Diputación de Barcelona (el parlamento regional, en el que el área de cultura actualmente está encabezada por un representante de Partido Conservador JxCat), por el Ayuntamiento de Barcelona (que por el contrario está gobernado por la izquierda) y por la Autoridad Portuaria de Barcelona.

La exposición temporal del Museo "Catalunya i Ultramar" (1995) ya había hecho referencia a la esclavitud y a la participación de las élites catalanas en los proyectos coloniales de España en África. Fue bien recibida por el público, pero no tuvo continuidad. La falta de recursos y un cambio en la dirección paralizaron desde 2017 la preparación de una exposición sobre el papel de la ciudad en el sistema económico plantacionista-esclavista, el tráfico de africanos, el comercio de mercancías producidas por los esclavizados, el retorno de capitales y los legados de la esclavitud, realizada en colaboración con el historiador Martín Rodrigo. En 2021 se paralizaron nuevas planificaciones expuestas en entrevistas de enero 2020 para una gran exposición sobre el tema, que debería mostrar objetos prestados de muchos museos ${ }^{18}$.

La exposición permanente renovada (inaugurada en enero 2020) trata sobre el comercio catalán con las Américas, incluyendo el tráfico de africanos. Los esclavizados están representados como mercancías y como víctimas: en un mapa sobre el comercio están simbolizados por cadenas y se reproduce la imagen del abolicionismo blanco: el esclavizado aparece de rodillas pidiendo su libertad. Una instalación simula un barco traficante, en el cual los africanos comercializados aparecen como sombras. En una esquina se muestran fuentes escritas y una pintura sobre la trata cuyas explicaciones repiten los títulos de las fuentes históricas ${ }^{19}$ sin una contextualización.

No se conecta el tema con los prohombres barceloneses. El traficante de africanos Antonio López, y los comerciantes con Cuba y defensores de la esclavitud Joan Güell y Miquel Biada (Rodrigo, 2000, pp. 18-25, 71-76; Solà, 2012, p. 75) aparecen como héroes de la modernización. No se hace mención a los orígenes de sus riquezas en el colonialismo

\footnotetext{
${ }^{17}$ Entrevista con Martín Rodrigo, 3.2.2020, con Josep Fradera, 6.2.2020, Universidad Pompeu Fabra, y con Javier Laviña, 11.2.2020, Universidad de Barcelona.

${ }^{18}$ Entrevista con Enric Garcia i Domingo, Jefe del Área de Colecciones e Investigación, 11.2.2020, con Josep Fradera, co-organizador de la exposición de 1995, 6.2.2020, con Martín Rodrigo, 20.2.2020, correo electrónico de Martín Rodrigo del 9.2.2021.

${ }^{19}$ Se cita por ejemplo la "Prórroga de 1804 de la real cédula expedida por el Rey Carlos IV en 1789 relativa al fomento del comercio de esclavos en las colonias de América" y el "Apresamiento escandaloso de la corbeta española Conchita de la propiedad de D. José Vidal y Ribas por el vapor crucero inglés Firelly (...) en la rada de Wydah (...) 27 de agosto de 1857”.
} 
y la esclavitud. Una exposición temporal trata siete temas conectados con "Catalunya i el mar”. El tráfico de africanos aparece contextualizado con las migraciones. Se muestra el ex-voto del barco traficante "Uracan”. El comentario dice "¿Sabías qué? En 1807 Gran Bretaña no solo abolió el tráfico de esclavos sino que se dedicó a perseguir a cualquier otro barco que lo practicase. En este exvoto, los negreros españoles dan las gracias por haber podido huir de la Royal Navy". Abajo se explica que "(...) millones de africanos fueron secuestrados y llevados a las colonias europeas para ser explotados como esclavos. (...)". Los únicos actores del tráfico mencionados en el texto completo son los capitanes negreros. Así se refuerza la idea de que los "negreros" eran algunos hombres malos y se omiten los beneficios para toda la sociedad catalana, por supuesto muy desigualmente repartidos entre la élite y los trabajadores.

Fuera de los museos había dos iniciativas de una conmemoración crítica del pasado esclavista: el gobierno municipal de Ada Colau realizó una serie de eventos sobre este tema e invitó al experto Martín Rodrigo (2018) a hablar sobre el pasado colonial y esclavista con ocasión de la diada nacional de Cataluña en 2018, retiró el 4 de marzo de 2018 la estatua del traficante de africanos esclavizados, Antonio López y López, Marqués de Comillas, del pedestal del monumento (que queda con las descripciones que le honoran) en la plaza que todavía lleva su nombre y se estableció un atril (muy pequeño y difícil de encontrar) que explica su historia (Figura 1$)^{20}$. La asociación "Conocer Historia" ofrece rutas guiadas sobre las huellas de la esclavitud y el abolicionismo, asesorados por el historiador Javier Laviña, y con un folleto financiado por el sindicato Comisiones Obreras a iniciativa de su archivista Javier Tebar (Guzmán, Berenguer y Laviña, 2018). ${ }^{21}$

Figura 1. Pedestal del monumento al traficante de africanos Antonio López en Barcelona, con inscripciones explicativas de facto ilocalizables delante de los coches, al fondo a la izquierda

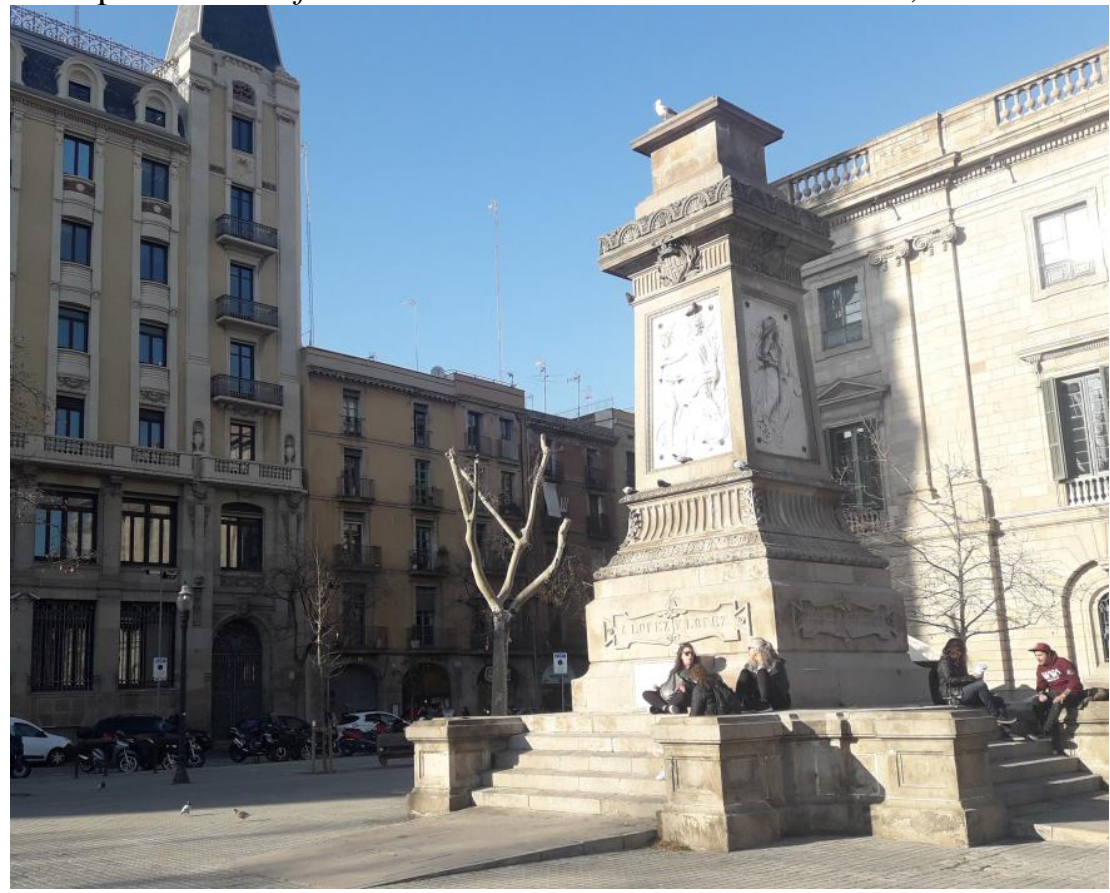

Fuente: Ulrike Schmieder, 19/2/2020

\footnotetext{
${ }^{20}$ Entrevista con Ricardo Vinyes, Comisionado de los programas de Memoria, 2015-2018, responsable de este acto público, 18.2.2020.

${ }^{21}$ Entrevista con Javier Laviña y Javier Tebar, 3.2.2020, Omar Guzmán y Oriol López, historiadores y guías, 12.2.2020, 20.2.2020.
} 


\section{Discusión de los resultados sobre museos españoles desde una visión comparada de museos en otros países europeos}

A pesar de estos pequeños pasos hacia una memoria crítica en Barcelona, la memoria de la esclavitud atlántica y la presencia africana/afroantillana en la Península es casi inexistente: la agencia y resistencia de los cautivos no se mencionan, como tampoco se comentan las actividades de los abolicionistas blancos, ni las consecuencias a largo plazo que conllevó la esclavitud. Las voces de los esclavizados no están expuestas en ningún lugar, aunque algunas de las mismas están publicadas (véase el apartado sobre Cuba). Dado que la situación de los afrodescendientes en España está marcada por un racismo feroz y por su exclusión de posiciones de liderazgo en la política, la administración, el sector privado, las instituciones culturales y la academia, las Naciones Unidas recomiendan al Gobierno de España: "El Gobierno debería revisar asiduamente los libros de texto y otros materiales educativos para asegurarse de que reflejan con precisión los hechos históricos relativos a tragedias y atrocidades del pasado, en particular la esclavitud, la trata de esclavos africanos y el colonialismo. El Gobierno debería dar una mayor visibilidad a la historia y la cultura de los afrodescendientes a través de museos, monumentos, las artes visuales y otros medios" (United Nations Human Rights Council, 2018, Recomendación 72). Todos nuestros interlocutores de la comunidad afroespañola/afro-cubana reafirmarían esta recomendación ${ }^{22}$. Sin embargo, lamentablemente se les excluye de los grupos de trabajo que definen las políticas relativas a la memoria del pasado histórico.

La situación en el Reino Unido y en Francia es diferente. El discurso histórico hegemónico de las élites blancas es, como mínimo, respondido por los afroantillanos y sus aliados en la sociedad civil local, lo cual ha derivado en un paisaje museológico diversificado. Nuevos sitios de memoria con un enfoque descolonizador han sido creados paralelamente a museos y monumentos heredados de la época colonial y su imaginario colectivo.

Para realizar la comparación se hace referencia al Docklands Museum en Londres y el International Museum of Slavery en Liverpool, el Musée d'Histoire en Nantes y el Musée du Nouveau Monde en La Rochelle ${ }^{23}$. Londres no fue solamente la capital del imperio colonial británico, sino también el segundo puerto inglés del comercio de africanos (Morgan, 2007, p. 21). Por otro lado, atrajo tanto al capital del esclavismo en las colonias inglesas como a los centros de la denominada "segunda esclavitud" ${ }^{24}$, lugares de

\footnotetext{
${ }^{22}$ Entrevista con Antumi Toasijé (historiador, fundador Centro Panafricano Madrid, 29.9.2019), Clara Caballero (arquitecta y activista afrocubana, 2.10.2019), Juan Carlos Rocabruno (médico y activista afrocubano, 8.10.2019), Diveika Kiemba (fundador del Centro Euro África Barcelona, 10.2.2020), Tony Romero (productor afrocubano de documentales, Ávila, 9.10.2019).

${ }^{23}$ En París solamente el Musée du Quai Branly menciona la trata de africanos en su departamento de África, y la esclavitud y herencia religiosa de África en Brasil y Haití en el Departamento de América. Los historiadores que estudian la esclavitud y las asociaciones antillanas demandan el establecimiento de un museo nacional de la esclavitud en la capital. Hasta ahora el Presidente Macron apoyó la Fondation pour la memoire de l'esclavage (inaugurada 13.11.2019) y un gran memorial para las víctimas de la esclavitud en el Jardin des Tuileries planificado para 2022, pero no consintió en establecer un museo en París.

${ }^{24}$ La "segunda esclavitud" es un concepto desarrollado por Dale Tomich y Michael Zeuske, ahora ampliamente utilizado por la comunidad internacional de historiadores/as de la esclavitud. Esta esclavitud está caracterizada por su carácter expansivo, la concentración masiva de trabajadores esclavizados para cultivar y procesar productos para el mercado mundial y la aplicación de nuevas técnicas. Se trató más de
} 
producción de café de Brasil (Solow, 1987), de algodón de Estados Unidos (Beckert, 2015) y de la industria azucarera de Cuba. Estos productos eran traídos por compañías inglesas que actuaban en la isla, pero también por los "negreros" hispano-cubanos, que fueron global players, como Pedro Juan de Zulueta, Julián de Zulueta, José Antonio Suárez de Argudín, Carlos Drake, Tomás Terry, entre otros (Bahamonde/ Cayuela, 1992, Marrero Cruz, 2006, Rodrigo, 2015).

Esta dimensión global está ausente en la correspondiente galería del Docklands Museum ${ }^{25}$ que revela muy detalladamente la implicación de los comerciantes londinenses en la trata y el esclavismo en la economía de plantación. La agencia y la resistencia de los africanos como sujetos de la historia juegan un papel importante, puesto que se nombra a los africanos y afrocaribeños abolicionistas (Olaudah Equiano, Ottobah Cuguano, Phyllis Wheatley, Robbert Wedderburn). Además, se aporta información sobre la lucha de los afrodescendientes contra el racismo del siglo XX, el legado del esclavismo del siglo anterior.

Liverpool fue la capital mundial del comercio de africanos esclavizados, contando con aproximadamente 5000 viajes realizados y 1,4 millones de personas traficadas (Tibbles, 2018, pp. 1, 4). El museo de la ciudad tiene un enfoque parecido al de Londres, pero trata también otros aspectos. Alrededor de una maqueta de una plantación azucarera en St. Kitts se pueden accionar pantallas para visualizar testimonios que describen las viviendas de los esclavistas y de los esclavizados, la comida, el trabajo, la tortura y la huida de ellos. Entre los testimonios encontramos a mujeres que fueron esclavizadas en el Caribe inglés y en los Estados Unidos, como Mary Prince, Mary Reynolds, Harriet Jacobs, y Sarah Wilson, a hombres esclavizados en Cuba como Esteban Montejo y Juan Francisco Manzano, y a Pompée Valentin de Vastey de Haití. Se dedican varias vitrinas a la resistencia de los esclavizados y sus descendientes. Asimismo, una muralla de imágenes muestra a intelectuales africanos y afrodescendientes de los siglos XX y XXI.

Los museos de Londres y Liverpool fueron creados con una alta participación de las comunidades afrocaribeñas locales. Ambos museos están involucrados en las actividades del día 23 de agosto, Día Internacional del Recuerdo de la Trata de Esclavos y de su Abolición, que coincide con el aniversario del inicio de la revolución haitiana. Las actividades en Liverpool de 2019 consistieron, entre otras, en organizar una marcha desde el centro de la ciudad hasta el museo que se encuentra junto al dique; celebrar una ceremonia de la comunidad afrocaribeña local ( 23 de agosto) para honrar a sus ancestros a la orilla del mar frente al museo; y, en la noche anterior en el mismo museo, proceder a una lectura realizada por el autor Johny Pitts, de su libro Afropean. Notes from Black Europe $^{26}$. Así, los museos se convirtieron en verdaderos lieux de mémoire. Cabe mencionar que ambos museos también han producido material educativo para las escuelas junto con el Wilberforce Institute for the Study of Slavery and Emancipation (Benjamin, 2012, p. 181).

una industria en el campo que de agricultura tradicional. Se refiere a los nuevos centros de la esclavitud del siglo XIX arriba mencionados después de la crisis de los centros de la antigua esclavitud en las Antillas francesas y británicas (Tomich/ Zeuske, 2008, 92-93).

${ }^{25}$ Visita 6.6.2017.

${ }^{26}$ La autora agradece a Charles Forsdick (University of Liverpool) la información y una conversación reveladora el 23.8.2019. 
Nantes fue el puerto de tráfico de africanos más importante en Francia, por el que pasaron más de 1700 expediciones negreras y más de medio millón de cautivos secuestrados. Como segunda ciudad, por delante de Burdeos y por detrás de La Rochelle, puertos tres y dos de Francia (Augeron y Caudron 2012, p. 7), rompió el silencio con una gran exposición sobre la trata mostrada desde 1992 hasta 1994. A partir del año 2007, el Museo de la Historia dedica varias salas a los temas del tráfico y de la esclavitud bien documentadas, aunque muy concentradas en el tráfico de africanos como una rama de la economía, es decir, los productos de los mercados africanos y de las Antillas. Se muestra una maqueta de una plantación en Saint-Domingue, en la cual aparece información sobre el trabajo de los esclavizados y los instrumentos de tortura. Igualmente, se mencionan las fugas y la revolución haitiana como forma de resistencia. Krystel Gualdé, directora científica del museo de Nantes, es consciente de que con las fuentes mostradas, producidas por los comerciantes o propietarios de africanos, los esclavizados "se quedan mudos"27. Una respuesta a este vacío es el programa artístico "Expression(s) decoloniale(s)". Para la próxima reforma de las salas descritas, la conservadora presenta la idea de exponer grabaciones de entrevistas con descendientes de personas esclavizadas (Bilé, Roman, y Sainte-Rose, 2011) en la sala sobre la abolición de la esclavitud. Algo particular de este museo es el amplio uso que hacen de él las escuelas que en muchos casos lo visitan junto con el gran Monumento a la Abolición de Esclavitud y el paseo urbano sobre las huellas de tráfico y esclavitud ${ }^{28}$. Además, los museólogos incluyen rápidamente los resultados de estudios científicos sobre estos temas publicados particularmente en la revista Cahiers des Anneaux de la Mémoire, editada por una asociación muy activa en el campo de la historia desde la primera gran exposición sobre Nantes y la esclavitud en 1992-1994. Su divulgación va dirigida a un público más amplio (Hourcade, 2014, pp. 196-202) $^{29}$.

En el Museo del Nuevo Mundo en La Rochelle, dedicado a las relaciones de la ciudad portuaria con las Américas, Canadá, Luisiana y la Antillas, aparecen los mismos temas que en el museo de Nantes, en las salas sobre el tráfico de africanos y las plantaciones de los rocheleses en Saint-Domingue. Una pintura remite a las rebeliones a bordo de los barcos de la trata. En la Corte del museo, antigua residencia del esclavizador AiméBenjamin Fleuriau, se encuentra una estatua muy alta de Toussaint Louverture, líder de la revolución haitiana, obra de Ousmane Sow en 2015. El rebelde en la casa del amo es una gesta fuerte. Sin embargo, los documentos que reflejan las voces de los esclavizados no están expuestos ${ }^{30}$. Una de las causas de este vacío en los museos es la tardía edición de fuentes de este tipo (Oudin-Bastide, 2008; Rogers, 2015; Régent, Gonfier y Maillard, 2015).

27 Entrevistas 17.10.2019, 5.11.2019 (la última con Bertrand Guillet, director del museo). Visitas 17.10.2019, 2.11.2019.

${ }^{28}$ En el año escolar 2017-2018, 35999 alumnos/as visitaron el museo, particularmente del Collège (más de 14 000), pero también de la escuela primaria (más de 10 000) y del Lycée (más de 6 000), y de escuelas profesionales y superiores (Chateau des ducs de Bretagne, Chiffres clés 2018, recibido de Laurence D’Haehne, Chargée du développement et de la politique des publics del museo por correo electrónico, 10.12.2019).

${ }^{29}$ Para ver los temas de la revista: https://www.anneauxdelamemoire.org/les-cahiers-des-anneaux-de-lamemoi. Para ver la serie de ponencias públicas: https://www.anneauxdelamemoire.org/blog 20.11.2020.

${ }^{30}$ Visitas 7.11.2019, 14.11.2019. Entrevistas con la conservadora actual, Mélanie Moreau, 12.11.2019, y la conservadora responsable del enfoque más fuerte sobre el pasado esclavista desde 2009, Annick Notter, 6.11.2019. 
Otros silencios que se encuentran en ambos museos tienen que ver con dos aspectos. Por un lado, la historia colonial del período postesclavista (expuesta en los museos ingleses): los recién liberados no recibían tierras, libertad o educación, sino que fueron obligados a continuar trabajando para los terratenientes blancos bajo pésimas condiciones a través de 'leyes sobre la vagancia' y contratos de arrendamiento restrictivos (Lara, 2005; Schmidt, 2009; Schmieder 2017, 239-272). Por otro lado, la indemnización a los propietarios (también silenciada en los museos ingleses ${ }^{31}$ ): Haití fue obligada en 1825 a pagar una altísima suma de dinero al Estado francés para compensar a los colonos que habían perdido tierras y trabajadores esclavizados como requisito para ser reconocida como Estado independiente (Beauvois, 2010), y la segunda abolición de 1848 estuvo acompañada por una ley de indemnización (Ernatus, 2009) que fue pagada a los esclavistas, y no a los esclavizados. Por su parte, ningún museo español tematiza la indemnización pagada a los esclavistas puertorriqueños después de la abolición de la esclavitud en 1873 (Díaz Soler, 1970, pp. 349-371).

Para explicar las diferencias con respecto a la conmemoración del pasado esclavista entre Gran Bretaña y Francia, por una parte, y España, por otra, hay varias cuestiones relatadas por diversos entrevistados, historiadores y políticos municipales:

1) Todavía existen numerosos conflictos sobre la memoria de la guerra civil española y de la dictadura franquista, cuya herencia no ha sido superada. El concepto de memoria histórica está relacionado exclusivamente con este legado del siglo $\mathrm{XX}^{32}$. Parece ser más urgente para los sucesivos gobiernos, tanto del Estado central como de las comunidades autónomas, homenajear a los republicanos de la Segunda República y a las víctimas de la dictadura, así como rebautizar calles y plazas que todavía llevan nombres de hombres falangistas. Estas prioridades son comprensibles, aunque no se presta atención a las fuentes coloniales-esclavistas del pensamiento nacionalista-expansionista y colonialista-racista del franquismo, así como tampoco a los orígenes económicos de las élites conservadoras que mayoritariamente apoyaron la dictadura.

2) Una parte importante de la población española se mantiene aferrada a la idea de un pasado imperial supuestamente glorioso para España en el que el país habría llevado la civilización y la evangelización a vastos territorios y pueblos del mundo. Esta glorificación contrasta con la catástrofe demográfica de los indígenas en las Américas después de la conquista (Sánchez-Albornoz, 1994, pp. 54-61) y con el sufrimiento de los africanos esclavizados. Esa falta de voluntad de descolonizar la mente se refleja en el enorme éxito del libro Imperiofobia (Roca Barea, 2016) a pesar de sus graves errores historiográficos (Straehle, 2019).

3) Las comunidades afrodescendientes del Reino Unido y de Francia son cuantitativamente más importantes, están mejor organizadas y son más influyentes que las de España. Los afroantillanos se autodefinen como descendientes de los esclavizados y han conformado un verdadero movimiento para defender sus derechos y exigir su inclusión en la historia nacional y sus representaciones (Gueye 2011, Benjamin 2012). Por el contrario, muchos

\footnotetext{
${ }^{31}$ Sobre la indemnización inglesa: Draper, 2010.

${ }^{32}$ En este análisis coincidieron, entre otros, Martín Rodrigo, 3.2.2020, Javier Laviña, 11.2.2020, José Miguel López, Universidad Autónoma de Madrid, 3.10.2019, 5.10.2019, y Fernando Osuna, historiador en la Fundación Municipal de Cultura, Cádiz, 18.9.2018. Las ideas de este párrafo fueron elaboradas en cooperación con Martín Rodrigo.
} 
afrolatinoamericanos en España se identifican en mayor medida con América Latina y sus nacionalidades que con África y, en el caso de los africanos, hay un interés menor cuando se trata de conmemorar la esclavitud atlántica. Además, los refugiados procedentes de África tienen problemas más graves (aquellos vinculados a la supervivencia) que la ausencia de políticas de memoria histórica. Por este motivo, el movimiento afroespañol es relativamente débil. Asimismo, son más infrecuentes los lazos entre académicos y activistas que en Francia y en Gran Bretaña, de modo que los eventos organizados por este movimiento pasan bastante desapercibidos por los universitarios ${ }^{33}$.

\section{Cuba}

\section{Análisis de los museos}

Cuba ha estado marcada por casi 400 años de esclavitud y, particularmente, por la "segunda esclavitud" de carácter industrializado en el siglo XIX, en la que existían ingenios en los que trabajaban cientos de africanos encerrados en barracones durante la noche. Estos, principalmente hombres, murieron a menudo de forma prematura, exhaustos por trabajar 12 horas en el campo y la mitad de la noche en el molino de azúcar durante la zafra, o siendo víctimas de tortura a consecuencia del miedo de los blancos ante un segundo Haití en Cuba. Muchos murieron sin haber podido formar jamás una familia (Zeuske, 2004, pp. 237-243, 310-320). Por supuesto, la memoria de la esclavitud en la isla está más presente en el espacio público que en España. No obstante, sorprendentemente, tiene menor presencia de lo que se podría imaginar dada la idea de que el socialismo representa a los oprimidos y a los explotados. No se ha proclamado ningún día nacional de memoria de la esclavitud y de la resistencia ${ }^{34}$, y tampoco se celebran los días conmemorativos de la esclavitud y la resistencia internacionales. Ni en La Habana, capital del país, ni en Matanzas, capital de la provincia más afectada por la "segunda esclavitud" en el Oeste de Cuba, existe un monumento para los esclavizados, sea como víctimas o como rebeldes. Los monumentos que honoran a los cimarrones o a los esclavizados rebeldes están en lugares muy alejados de La Habana (Santiago de Cuba) o difícilmente accesibles (Triunvirato) ${ }^{35}$.

En La Habana, la Casa de África, institución líder de la Ruta del Esclavo en Cuba, se encuentra al lado del Museo del Palacio del Segundo Cabo, ${ }^{36}$ el único lugar de la ciudad que trata el tema esclavitud detalladamente. El director de la Casa de África es Alberto Granado Duque, blanco, como prácticamente todos los directores de museos, quien ha participado en programas de ayuda civil en Sao Tomé y Príncipe y Angola. Frente a un grupo de estudiantes de diferentes países africanos en enero de 2019, explicó que el

\footnotetext{
${ }^{33}$ El Festival Afro-Conciencia a finales de septiembre de 2018 y las protestas contra el Día de Hispanidad (12 de octubre) de aquel año en Madrid representaban contramemorias del colonialismo español en África y -en menor medida - del esclavismo en las Américas. Sobre la composición de la población afrodescendiente y el movimiento panafricanista en España, véase Toasije, 2014.

${ }^{34}$ Podría ser, por ejemplo, el 14 marzo como aniversario de la conspiración de Aponte (1812) o el 5 de noviembre, el primer día de la rebelión de Triunvirato (1843).

${ }^{35}$ La autora visitó el Monumento y el Museo al Esclavo Rebelde en el ingenio Triunvirato (8.2.2019, 23.2.2019). Por los límites de espacio en el presente artículo, no se ofrece una descripción de estos espacios que merecería incluirse en una crítica más profunda. Serán, pues, objeto de otras publicaciones.

${ }^{36}$ En el Museo del Palacio del Segundo Cabo, visitas el 10.1.2019, 29.1.2019, y 9.3.2019, el tema de la esclavitud aparece tratado en un documental sobre los orígenes de la población cubana, en una cronología de la historia de Cuba y en elementos interactivos sobre industria y comercio. Además hay un filme sobre la esclavitud y la cultura afrocubana, lamentablemente reducido a "Arte, religión y emotividad".
} 
objetivo del museo era "dar a conocer a los cubanos la historia y cultura africana subsahariana". Destacó que África, antes del tráfico de esclavizados y el colonialismo, era un continente rico y desarrollado que contaba con grandes imperios. Sin embargo, después de este período, África se transformó en un continente empobrecido, marcado por conflictos étnicos y lingüísticos. Por otra parte, subrayó la rebeldía esclava y recordó que Fidel Castro había puesto el nombre de Carlota a la misión militar en Angola, en honor a la lideresa de los rebeldes del ingenio Triunvirato en 1843 (sobre la rebelión: Franco, 1978; Finch, 2015) ${ }^{37}$.

La única sala sobre la esclavitud que tiene la Casa de África muestra retratos de barcos del tráfico de africanos, instrumentos de trabajo y de tortura, un molino y calderas, pinturas de ingenios, una obra de arte mostrando la tortura de los esclavizados, anuncios de africanos esclavizados prófugos en periódicos y un listado de rebeliones acompañado de un retrato de José Antonio Aponte, el líder de la conspiración antiesclavista y anticolonial de 1812, inspirada en Haití (Childs, 2006). La perspectiva es economicista, de acuerdo con los conceptos de Moreno Fraginals (1978) y no está presente la voz de los cautivos que aparece en las peticiones de los esclavizados a los síndicos de esclavos. Así pues, sería deseable que se incluyeran los resultados de los estudios más recientes sobre la trata clandestina de africanos (por ejemplo, Barcia et al., 2017).

En una tabla explicativa sobre las insurrecciones de los esclavizados de 1843, se expone: "[1] os hechos demostraron la rebeldía anticolonial y antiesclavista de los africanos y sus descendientes. Para el dominio español estas acciones constituyeron un gran peligro que se reprimió mediante 'la salvajada sangrienta de O’Donnell' en 1844”. Este texto sugiere que la resistencia de los esclavizados no se dirigía contra la mayoría de los esclavistas, es decir, criollos blancos, y que estos últimos no habían tolerado la represión de las rebeliones. En otras palabras, en todo momento se conecta el esclavismo con el colonialismo español, y se omite el papel de la sacarocracia (la aristocracia propietaria de los ingenios) y de los otros esclavistas criollos cubanos, propietarios de cafetales o haciendas tabacaleras. Esta narrativa incluye el mito de que los propietarios cubanos habrían liberado a sus esclavizados con el inicio de la Guerra de los Diez Años (1868) y la abolición de la esclavitud por la constitución de Guáimaro (1869). De ahí en adelante, cubanos blancos y negros habrían luchado juntos por la independencia. En realidad, solamente una minoría de esclavistas cubanos se adhirió al movimiento de 1868. En la parte del país controlada por los independentistas, los libertos fueron coaccionados para participar en la lucha armada o para trabajar para los mismos. Asimismo, los soldados afrocubanos fueron discriminados en el seno del Ejército Libertador y el liderazgo blanco firmó una paz sin emancipación para los esclavizados (Ferrer, 1999, pp. 26-37, 60-89). Lo que haría falta en La Habana — según los historiadores expertos en el tema- es un museo nacional de la esclavitud ${ }^{38}$.

El Museo de la Ruta del Esclavo es parte del proyecto de la 'Ruta del Esclavo' de la UNESCO, que contribuyó una única vez a la financiación del museo con 30 mil dólares

\footnotetext{
${ }^{37}$ Entrevista y participación en una ruta guiada, 15.1.2019, documentación del museo 9.1.2019.

${ }^{38}$ El grupo de investigación sobre la esclavitud en La Universidad de la Habana (María del Carmen Barcia, Mercedes García, Miriam Herrera, Oilda Hevia, Julio Rojas) intentaron hacer un museo del ingenio llamado seguidamente San Andrés, Nuestra Señora del Carmen, Toledo, Apuro y Manuel Martínez Priego en Marianao, en función entre fines del siglo XVII y 2000, pero el proyecto fue cancelado por el Gobierno. Entrevistas con María del Carmen Barcia y Mercedes García, 15.1.2019 y 22.1.2019.
} 
en 1998. El museo abrió sus puertas en el año 2009 y se encuentra en el Castillo de San Severino, en la periferia de Matanzas, y es difícil acceder con transporte público desde el centro de esta ciudad y la zona turística de la isla. El museo es muy poco visitado ya que no forma parte de las rutas turísticas, aunque acuden a visitarlo académicos y estudiantes nacionales e internacionales, así como alumnos de las escuelas locales. El equipo de museólogas, incluyendo a su directora Isabel Hernández quien demuestra un gran entusiasmo y está involucrada en el proyecto desde sus inicios, trata de hacer más atractivo el museo. Está previsto que se abra una segunda sala sobre esclavitud que incorpore elementos interactivos. Sin embargo, falta financiación para este proyecto y buena voluntad por parte de la ciudad. Uno de los problemas es que los autobuses no tienen una parada en frente del museo. Sin duda, esto podría ser solucionado sin gastos adicionales. El museo sirve como espacio para la organización de coloquios académicos y presentaciones de libros. Estudiantes de maestría de la Universidad de Matanzas reciben apoyo del museo si escriben sus tesis sobre rebeliones de los esclavizados ${ }^{39}$. La institución también colabora con las Casas de Santos de la ciudad. Oscar Rodríguez Pedroso, Babalawo de la Casa Arará y miembro del grupo de trabajo del museo, alabó mucho al equipo del Museo, aunque lamentaba la falta de dinero y de transporte ${ }^{40}$.

Por el momento, en el Museo de la Ruta del Esclavo hay una sola sala que trata la esclavitud a través del trabajo, la tortura y la resistencia mediante el cimarronaje. Otra sala está dedicada a las religiones afrocubanas, cuya existencia es un legado cultural del esclavismo. Sin duda, esta sala atrae público, pero el enfoque respalda una imagen folclórica sobre los afrocubanos y no hace referencia a los horrores de la esclavitud y sus legados, traducidos en desigualdad socioeconómica y discriminación racial. En la sala sobre la esclavitud se encuentran objetos como un mapa de África, fotografías de ruinas de ingenios, grabados de la época mostrando a africanos esclavizados, tambores, instrumentos de trabajo y de tortura, restos arqueológicos de antiguos palenques, un listado de insurrecciones, documentos del poder colonial sobre el tráfico de esclavizados en el puerto de Matanzas y retratos de personalidades afrocubanas como el líder político Juan Gualberto Gómez o la santera Bonifacia Alfonso.

En la lista de rebeliones de la provincia Matanzas aparecen conceptos como "rebeldías esclavas", "sublevación", "alzamiento", "levantamiento", "rebelión" e "insubordinación". Este último es problemático porque los esclavistas habrían utilizado esta palabra dando por sentado que los esclavizados les debían obediencia. Con respecto a los esclavizados se utilizan términos tales como "dotación", esclavo", "negro esclavo", "negro" o "mulato", un vocabulario que no ha sido descolonizado. La palabra "dotación" es un tecnicismo que convierte simbólicamente a seres humanos en mercancías con precio, cifras sin cara ni nombre. El término "esclavo", cuya connotación es todavía más negativa si aparece junto a "negro", sugiere que la esclavitud era el estatus natural de los africanos y los afrodescendientes. En realidad, los africanos fueron secuestrados y hechos cautivos, esclavizados a través de la violencia y el terror. La palabra 'esclavizado', enslaved, esclavisé, versklavt pone el énfasis en este proceso.

Las voces afrocubanas son transmitidas a través de la poesía de Nancy Morejón y Nicolás Guillén, aunque no toman la forma de las protestas de los esclavizados del siglo XIX o de historias familiares sobre la esclavitud. En los museos cubanos estatales se podría

\footnotetext{
${ }^{39}$ Documentación del museo y entrevistas con Isabel Hernández (8.2.2019, 14.2.2.2019).

${ }^{40}$ Entrevistas 15.2.2019, 18.2.2019.
} 
promover un enfoque más centrado en la perspectiva y las voces de los esclavizados y sus descendientes, si se comparte la visión de que una museología descolonizada debe dar la voz a las víctimas de colonialismo y de la esclavitud. Además, se omite la lucha de madres y padres esclavizados y libertos por la libertad de sus hijos y la reunificación familiar, a pesar de que los síndicos de esclavos, las juntas de patronato y los notariados dejaron miles de documentos que reflejan esta lucha (García, 1996, pp. 102-124; Schmieder 2017, pp. 173-180, 309-333).

La falta de voz de los esclavizados en los museos estatales no puede explicarse por la ausencia de estudios y colecciones de documentos (García, 1996, Barcia, 2003, Hevia, 2011, Perera y Meriño, 2015). Hay numerosas familias afrocubanas que todavía recuerdan las historias de la bisabuela y la tatarabuela sobre la esclavitud y las décadas posteriores $^{41}$. Una historia oral más allá de la narración de Esteban Montejo es posible.

La excepción es la Sala Museo, en la antigua y actual central "Álava” (actualmente "Méjico") cerca de la ciudad de Colón (Figura 2), dirigida por una maestra jubilada, Eneida Villegas Zulueta ${ }^{42}$, descendiente de los esclavizados del terrible traficante de africanos, esclavista y torturador, Julián de Zulueta. Este antiguo propietario de la central "Álava" y de 781 africanos esclavizados, era oriundo de Álava, País Vasco (Marrero Cruz, 2006, cifra 202). En este lugar se coleccionaron refranes ${ }^{43}$, vocabulario y nombres de los antiguos esclavizados e historias sobre costumbres cotidianas, ropa, peluquería, alimentación, medicina natural, con especial atención a las mujeres esclavizadas, y narraciones sobre los ancestros de Eneida Villegas, Ta Higienio y Ma Carlota. En este sitio los descendientes de los esclavizados se han apropiado de su historia y la transmiten a sus nietos con la colaboración de la escuela local.

Varios intelectuales afrocubanos que fueron entrevistados pedían una mayor memoria crítica de la esclavitud, aunque de manera más o menos radical ${ }^{44}$. Desean que se inaugure en La Habana un memorial para el héroe afrocubano José Antonio Aponte (lo cual ha sido prometido desde hace un tiempo a los miembros de la Comisión Aponte). Piden, asimismo, la apertura de un importante museo sobre la esclavitud, así como sobre el aporte de los afrocubanos a la historia nacional, por ejemplo, en la independencia. Además, quieren que se conmemore la lucha del Partido Independiente de Color contra

\footnotetext{
${ }^{41}$ Entrevistas con Gloria Rolando, productora de documentales históricos, 11.1.2019, Georgina Herrera, poetisa, 17.1.2019, Graciela Chailloux, economista, Universidad de La Habana, 23.1.2019, Daisy Rubiera Castillo, antropóloga, 28.1.2019 en La Habana, Julián Hernández Jova, presidente de la Asociación de los Hijos de San Lázaro en Guanabacoa, 5.2.2019, Ana María Gazmurri García, Ela Francisca Silveira Alfonso, Rosa Alfonso, descendientes de los esclavizados del ingenio Triunvirato en Cidra, 16.2.2019, Oscar Rodríguez Pedroso, en Matanzas, 15.2.2019, 18.2.2019, Mercedes Lugones Marín, mayordoma del Cabildo San Antonio en Trinidad, 4.3.2019, Mariuski Zúñiga Iznaga, Pedro Francisco Marín, Gonzalo Francisco Marín, descendientes de esclavizados en Manaca, 1.3.2020.

${ }^{42}$ Entrevista y visita guiada 22.2.2020.

${ }^{43}$ Hay tristeza y trauma en este refrán: "Cuando mi trata mi amo con mucho señorío me tiene regalao o me tiene vendío."

${ }^{44}$ Entrevistas con Gloria Rolando, 11.1.2019, Heriberto Feraudy, escritor y diplomático, antiguo presidente de la Comisión Aponte, 14.1.2019, Tomás Fernández Robaina, investigador en la Biblioteca Nacional, 16.1.2019, Roberto Zurbano, experto en ciencias literarias, caído en desgracia, 2.2.2019. Graciela Chailloux, Georgina Herrera, Daisy Rubiera Castillo, Gisela Arandia, antigua jefa de Color Cubano, 5.2.2019, Esteban Morales, economista, miembro de la comisión Aponte, 31.1.2019, Maritza López McBean, co-fundadora Red Barrial de Afrodescendientes, 11.3.2019, Nicolás Hernández Guillén, presidente de la Fundación Guillén, 15.3.2019.
} 
el racismo en la neocolonia, como denomina la historiografía y museología cubana al período de la República de 1902 a 1959, por su dependencia política y económica de los Estados Unidos. Por último, hubiesen deseado que para el 500 aniversario de La Habana en 2019 hubieran mencionado no solamente a los condes y los marqueses que vivían en los palacios restaurados, sino también a los esclavizados que construyeron esta belleza. No parece que alguien se tome en serio estas reivindicaciones.

Figura 2. Torre del barracón de la central Álava, hoy Méjico, con la entrada a la sala museo

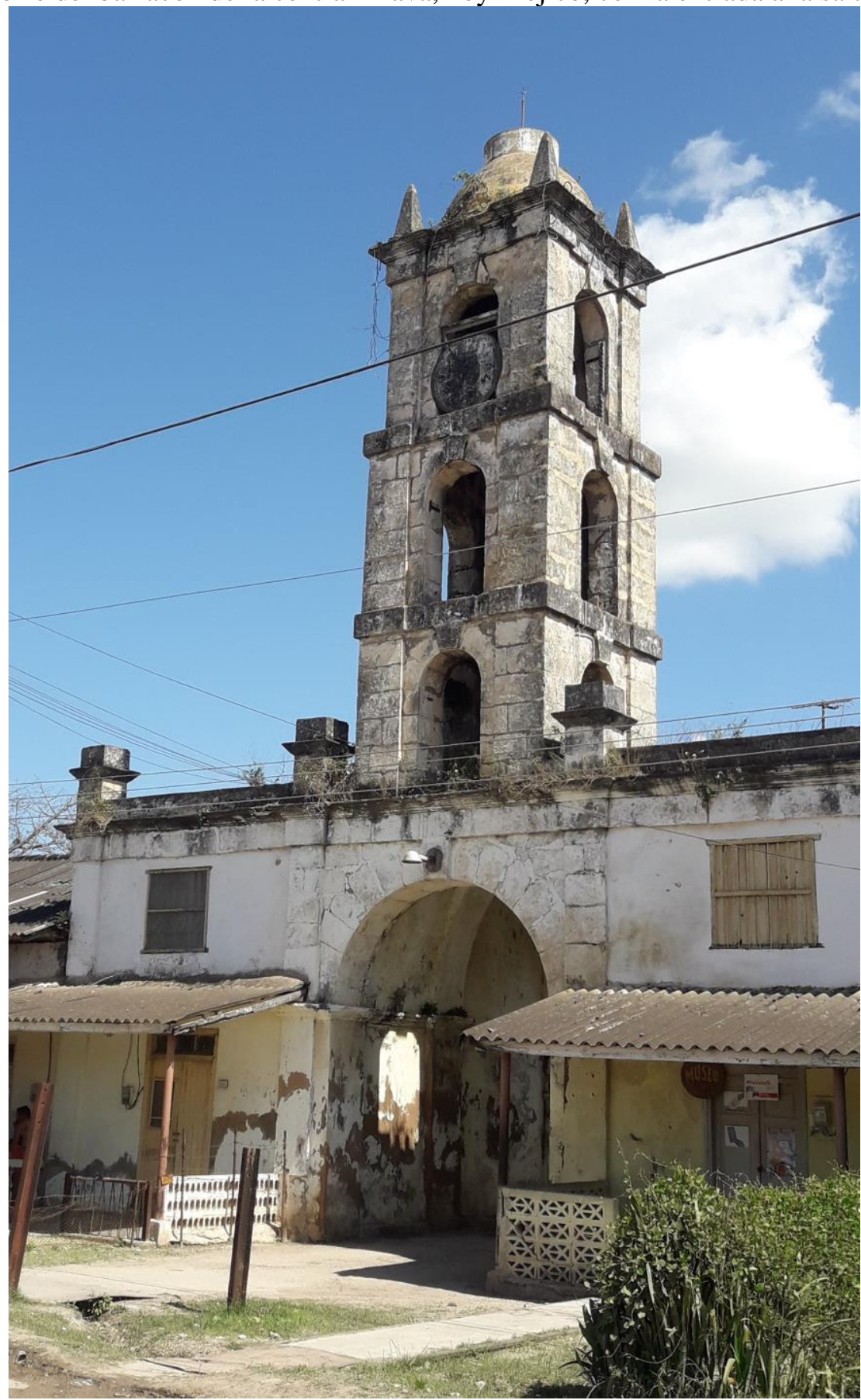

Fuente: Ulrike Schmieder, 22/2/2019

Las raíces de los silencios y olvidos sobre la esclavitud deben buscarse en la historia reciente. La Revolución de 1959 fue hecha por líderes de clase media blanca que oficialmente terminaron con la segregación racial, pero que también disolvieron las 
asociaciones afrocubanas, y prohibieron hablar sobre el racismo y practicar las religiones afrocubanas (Fuente, 2001, pp. 259-316). Los afrocubanos pudieron acceder a los sistemas de educación y salud, y en 1981 la esperanza de vida entre cubanos blancos y negros solo se diferenció por un año, comparado con Brasil, 6,7 años, y EE. UU., 6,3 años (Fuente, 2001, p. 309). No obstante, los revolucionarios socialistas narran una historia nacional a través de una imagen problemática sobre la unidad nacional en la que se refleja el discurso racista del siglo XIX e inicios del XX. Lo parafraseo: los líderes cubanos blancos habían tratado a sus esclavizados mejor que los propietarios estadounidenses, ingleses o españoles, y dieron la libertad a sus esclavizados en 1868. Las guerras de la independencia, ganadas conjuntamente por cubanos blancos y negros, habrían terminado con la esclavitud y el colonialismo a la vez. En la república neocolonial, entre 1902 y 1959, había discriminación racista, pero era fruto de la influencia norteamericana y estaba fomentada por la élite blanca alta, mayoritariamente colaboradora de los Estados Unidos. Este discurso omite, por una parte, el hecho de que el independentismo comenzó con la rebelión del negro José Antonio Aponte en 1812 y no con la del blanco Carlos Manuel de Céspedes en 1868, y, por otra, que los patriotas blancos traicionaron a sus compañeros negros en la matanza de los líderes del Partido de los Independientes de Color, aunque hubiesen sido sus antiguos hermanos en armas en 1912 (Castro Fernández, 2002). Se ignora la permanencia de prejuicios racistas en el socialismo, que resurgieron con vehemencia durante la crisis económica de la década de 1990. A partir de ahí, los afrocubanos han estado discriminados de nuevo en el mercado de trabajo, particularmente en el sector del turismo y en el sector de divisas en general, en el acceso a la educación superior, a una vivienda digna y a puestos dirigentes en organismos estatales. Además, no heredan casas que puedan alquilar a turistas, reciben una menor cantidad de remesas desde el extranjero debido a que, en general, la población blanca salió del país de forma más temprana, obteniendo mejores empleos en el exterior y, además, no se les concede la nacionalidad española porque sus ancestros no migraron desde este país hacia Cuba. Asimismo, prevalecen los prejuicios contra los matrimonios interétnicos (Fuente, 2001, pp. 317-334; Romay 2012, pp. 197-286).

Los prejuicios raciales se desarrollan sin que las personas que los tienen sean conscientes de ello. Negar el racismo cotidiano conlleva que en la vida diaria gran parte de los cubanos blancos exprese abiertamente sus prejuicios raciales sobre los afrocubanos calificándolos de "flojos", "mal educados", "supersticiosos", "violentos", "criminales" o "prostitutas", entre otros. En La Habana, una colega afrodescendiente de piel clara, casada con un afrodescendiente de piel muy oscura, contaba que, al dar a luz a una niña casi blanca, las vecinas estuvieron haciendo comentarios tales como "tienes la barriga muy limpia". En Cidra, las descendientes de los esclavizados contaban que al pasar un grupo de afrocubanos por su lado paseando, una mujer blanca reaccionó diciendo: "mira la negrada esa cómo viene por ahí". Las mismas afrocubanas descendientes de los esclavizados afirmaban detestar que la gente se dirigiese a ellas con las palabras: "tú, negra".

El gobierno socialista admitió en 1986 que había un problema con el racismo (Fuente, 2001, p. 312) y permitió el ejercicio de las religiones afrocubanas en 1991 (Rauhut, 2012, pp. 99-102). Aun así, cualquier debate excesivamente crítico se prohíbe con el argumento de que destruye la unidad nacional y es utilizado contra la nación cubana por el enemigo estadounidense, siendo este el más racista. Entre los años 2012 y 2014 hubo varias iniciativas estatales para combatir el racismo, asesorado por intelectuales afrocubanos, como por ejemplo aquellos que se reunían en la Comisión Aponte, fundada en 2009 como parte de la Unión Nacional de Escritoras y Artistas Cubanos. En los últimos años este 
afán se ha esfumado. Algunos activistas cayeron en desgracia como Roberto Zurbano, que pasó de la crítica intelectual al activismo social en favor de los más pobres del país, los migrantes afrocubanos del Oriente de Cuba. La Comisión Aponte todavía existe, pero su liderazgo se trasladó a funcionarios fieles al Partido Comunista, dejando de lado a la comunidad afrocubana. Aquellos afrocubanos que no tenían nada que perder fueron los que hablaron más abiertamente sobre esta cuestión. A una jubilada afrocubana, con una pensión equivalente a 10 euros al mes, ya no la podían castigar más. Algunos académicos afrocubanos más jóvenes expresaban sentir miedo a perder su trabajo y con ello sus relaciones con el exterior. Las únicas personas no blancas que dirigen un museo que se conocieron durante la investigación fueron las directoras del Museo de la Ruta del Esclavo en Matanzas y del Museo de Arqueología en Trinidad. Los demás directores de museos estatales, incluyendo los museos municipales de las comunidades afrocubanas de Regla y Guanabacoa, son blancos ${ }^{45}$, igual que las autoridades superiores de los gobiernos municipales y los departamentos de patrimonio. Así, acostumbran a ser cubanos blancos los que deciden sobre las historias que se transmiten en un museo, un manual escolar e incluso sobre lo que no se cuenta en las antiguas casas de esclavistas, convertidas en museos o lugares turísticos ${ }^{46}$.

Hasta que no exista un museo sobre la esclavitud en La Habana y en cada ciudad provincial que explique que la esclavitud en Cuba no fue más benigna que en los Estados Unidos, produciéndose incluso una mortandad más alta; hasta que no termine la idolatría a los líderes independentistas blancos del siglo XIX mayoritariamente con una mentalidad racista; hasta que no se admita que el propio hijo de José Martí, José Francisco Martí y Zayas-Bazán, traicionó las ideas de su padre participando en el banquete que festejaba la masacre de los Independientes de Color ${ }^{47}$, hasta que no se inaugure un monumento en honor a José Antonio Aponte en la capital y un museo que recuerde las contribuciones de los afrocubanos a la historia nacional; y hasta que no se tomen en consideración las propuestas de las asociaciones afrocubanas en este campo, no será posible combatir el racismo cotidiano.

\section{Museos y sitios de memoria en otras islas caribeñas}

A excepción de Haití, que se liberó a sí misma entre 1791 y 1804, las islas francesas en el Caribe continúan siendo parte de Francia, oficialmente no como colonias, sino como departamentos ultramarinos (desde 1946). En realidad, los habitantes del Caribe francés se encuentran todavía en una situación semicolonial, ya que numerosas leyes francesas, por ejemplo, las leyes de la seguridad social y de ayudas sociales del Estado a las familias, fueron introducidas con décadas de atraso (Stromberg Childers, 2016, pp. 70-72, 170171). El gobierno local quedó en manos de funcionarios blancos de la metrópoli y el poder económico en manos de los békés, descendientes de los esclavistas indemnizados por la

\footnotetext{
${ }^{45}$ Casa de África, Museo del Palacio del Segundo Cabo, Museo Municipal de Colón, Museo Histórico Provincial de Matanzas, Museo al Esclavo Rebelde en Triunvirato, Museo Municipal de Trinidad, Sitio de Guaimaró, Sitio de San Isidro.

${ }^{46}$ Sobre este tema podría escribir otro artículo. Ejemplos: el Museo de Obrapía en La Habana (residencia de los Marqueses de Cárdenas de Montehermoso, propietarios de varios ingenios), el Museo Romántico en Trinidad (residencia del Conde de Casa Brunet, "negrero" y poseedor de tres ingenios), los sitios de Manaca (residencia de la familia Iznaga en su ingenio) y Guaimaró (Palacio de José Mariano Borrell y Lemus, propietario de 1000 esclavizados) en el Valle de los Ingenios.

${ }^{47}$ Sobre el hijo de José Martí: José Francisco Martí y Zayas-Bazán - "Ismaelillo", Chief of Staff, Cuban Army, la Masacre de 1912, http:/www.afrocubaweb.com/history/josefranciscomarti.htm\#Eusebio 7.6.2020.
} 
pérdida de "sus" trabajadores esclavizados. Estos últimos son los grandes terratenientes, los propietarios de las cadenas de supermercados y gasolineras, los receptores de ayudas de la Unión Europea para la producción bananera y también los grandes empleadores. Nunca se ha realizado una reforma agraria, las tasas de desempleo y de la pobreza son más altas y el nivel educativo es más bajo que en la Francia hexagonal (Paquet, 2009, 8990).

Los békés mantienen lugares turísticos en antiguas plantaciones donde niegan o trivializan el pasado esclavista, como la Habitation Pécoul y el Musée du Rhum (destilería St. James) en Martinica, o la Plantation La Grivelière en Guadalupe (Reinhardt, 2006, Chivallon, 2006). Honoraban con un monumento y un museo a Joséphine de Beauharnais, hija de una familia de esclavistas martiniqueses (los Tascher de la Pagerie), esposa de Napoleón, quien restableció la esclavitud en las colonias francesas en 1802, después de haber sido abolida en 1794 por la Convención. El museo fue reformado recientemente incluyendo la historia de la esclavitud, de los esclavizados y sus descendientes ${ }^{48}$. La población afrodescendiente mayoritaria protesta regularmente contra el culto a la esposa del emperador. Su estatua en Fort-de-France fue decapitada por primera vez en 1991 (Reinhardt, 2006, pp. 150, 172) y retirada completamente en julio de 2020. Una reciente acción de protesta - muy controvertida - destruyó dos estatuas del abolicionista blanco Victor Schœlcher, en Fort-de-France y en la comuna de Schœlcher en mayo 2020, con el argumento de que se había posicionado a favor de la indemnización de los esclavistas $(\text { Sat, 2020) })^{49}$.

El rumbo en las políticas de memoria del pasado esclavista en Francia a partir de 1998, condujo - a través de un proceso lento, no inmediato - a la inauguración de museos, centros y monumentos dedicados a la historia de esclavitud y la emancipación en los departamentos ultramarinos antillanos, presentando a los esclavizados como víctimas o rebeldes y cimarrones ${ }^{50}$. La construcción más importante fue la del Mémorial ACTe, "Centro caribeño de expresión de las memorias de la trata y de la esclavitud" en Pointeà-Pitre, Guadalupe (Dorigny, 2018, pp. 188-190). El centro fue inaugurado el 10 de mayo de 2015 por el presidente François Hollande, en presencia de los jefes de Estado de Senegal, Malí y Haití (L'inauguration du Mémorial ACTe, entre symboles et messages forts, 2015). Es un espacio ambiguo que funciona como memorial, museo, centro educativo y lugar de eventos culturales. Los guadalupeños en Francia se sienten muy

\footnotetext{
${ }^{48}$ Entrevista virtual con la historiadora responsable de la reforma, Jessica Pierre-Louis, 1.3.2021.

49 La verdadera postura de Schœlcher acerca de la indemnización se explica aquí: https://oliwonlakarayib.com/quel-est-le-role-de-victor-schoelcher-dans-labolition-de-lesclavage/

21.11.2020. Sobre el asunto de las estatúas destruidas se publicará en 2021: Schmieder, Ulrike, Controversial Monuments for Enslavers, Enslaved Rebels and Abolitionists in Martinique and Cuba, en un número especial de la revista Comparativ, Zeitschrift für Globalgeschichte und vergleichende Gesellschaftsforschung, un artículo basado en entrevistas con académicos y activistas martiniqueses y cubanos.

${ }^{50}$ En 1998 se inauguró el Memorial CAP 110, Mémoire et Fraternité, obra del escultor afro-martiniqués Laurent Valère y se estableció el monumento Nègre Marron (Nèg Mawon), obra del escultor afromartiniqués Hector Charpentier en Diamant en Martinica. También hay monumentos a cimarrones y rebeldes en Martinica en St. Esprit, Trois-Ilets y Lamentin y en el barrio Trénelle de Fort-de-France. En Guadalupe se construyó un monumento al cimarrón en Sainte-Anne. En el Boulevard des Héros en Guadalupe se honoran a Louis Delgrès, Solitude e Ignace (Jacky Poulier, 1999), los líderes de la insurrección contra la reintroducción de tropas napoleónicas en 1802. Para Louis Delgrès hay un gran memorial en la Fortaleza Louis Delgrès en Basse-Terre, Guadalupe, establecido en 2014. Dorigny/Zins, 2009, pp. 12-13, 212. Dorigny 2018, Nos. 84-85, 148-149. Reinhardt 2006, 143-147, 169-170, 172-174.
} 
orgullosos de haber obtenido esta gran institución ${ }^{51}$, mérito también de los esfuerzos del presidente regional Victorin Lurel, aunque en la isla se critica que el dinero invertido debería haber sido utilizado para luchar contra la desigualdad social extrema en el Caribe francés.

El Musée de la canne, museo de la caña, en la comuna de Trois Ilets de Martinica, institución estatal fundada en 1987 en el lugar de una antigua destilaría de Ron, es un sitio de difícil acceso con transporte público y se encuentra lejos de la capital o de cualquier ciudad mayor. Así, es difícil que los alumnos de las escuelas locales lo visiten. La exposición se centra mucho en la tecnología de la producción de caña y, a pesar de que las condiciones de trabajo y vida de los esclavizados y los trabajadores rurales después de la emancipación se mencionan, la exposición no está enfocada en este aspecto ${ }^{52}$. Por otra parte, la Savane des Esclaves, en Trois-Ilets, instalada en 2004 por Gilbert Larose como iniciativa privada, reconstruye "una aldea de entonces", y no solamente informa sobre la esclavitud sino también sobre las prácticas culturales y artesanales de raíz africana $^{53}$. El hecho de que exista este lugar de memoria creada por una iniciativa local muestra que el estigma de ser descendiente de esclavizados, lo cual en el pasado ocasionaba indiferencia e incluso rechazo por los memoriales a la esclavitud, desapareció para los intelectuales activistas afroantillanos y para la población rural afrodescendiente. Los descendientes de los esclavizados comienzan a apropiarse de su historia, se ven a sí mismos como agentes y sujetos resistentes y se enorgullecen de sus tradiciones culturales $\mathrm{y}$ artesanales.

Curação, antigua colonia holandesa, forma parte de la monarquía neerlandesa, que tiene competencias en defensa y política exterior. La isla se encuentra en un estatus ambiguo, a medio camino entre la dependencia y la independencia. Durante un congreso en 2012 se visitó el monumento Desenkadena (1998), al borde del mar, cerca de la capital. El monumento muestra a dos hombres y una mujer. El hombre situado en el centro del grupo rompe la cadena con un martillo. En un parque de la cercanía hay unas estelas sobre la lucha por la libertad que honoran a los líderes de rebeliones de esclavizados nacionales (por ejemplo, Tula, Pedro Wacao, Diana) e internacionales (Toussaint Louverture, Sam Sharpe, Aponte, Bussa, José Leonardo Chirino, Zumbí dos Palmares). En Curação está, además, el Museo Tula, abierto desde 2007, que conmemora el levantamiento de los esclavizados en el año 1795, y el museo Kura Hulanda de esclavitud en la capital Willemstad. El primero fue fundado por iniciativas locales y narra los eventos de la rebelión. Además, contiene información sobre las religiones afrocaribeñas y sobre su desarrollo tras la emancipación, y se organizan cursos y actividades dirigidas a la población local. El museo Kura Hulanda, fundado en 1999 por el empresario holandés Jacob Gelt Dekker, presenta una muy vasta colección de arte y objetos africanos, informa sobre el tráfico negrero internacional, la resistencia de los esclavizados en las Américas y las actividades abolicionistas de los afrodescendientes. Sin embargo, carece de información en cuanto al comercio de africanos esclavizados y la esclavitud local, aunque el museo está situado en un lugar vinculado con el tráfico negrero en la isla, y la corte de

\footnotetext{
${ }^{51}$ Entrevista con Frédéric Régent, antiguo presidente del CNMHE, 9.5.2018, Emmanuel Gordien, presidente de la asociación antillana CM98, 25.5.2018, Soria Adèle, realizadora de la obra de teatro "Mary Prince", 13.6.2018.

${ }^{52}$ Visita en febrero 2006. Criticado también por Christine Chivallon (2006).

${ }^{53} \mathrm{La}$ Savane des Esclaves, https://www.lasavanedesesclaves.fr/, 7.6.2020.
} 
comerciantes, desde donde numerosos esclavos fueron vendidos a la Tierra Firme de Hispanoamérica $^{54}$.

El Caribe inglés, independiente desde los años 1960, cuenta con una Universidad (University of the West Indies con entidades en Jamaica, Barbados y Trinidad) en la que se estudia desde hace décadas la historia de la esclavitud con intensidad. Se establecieron sitios y rutas de memorias, como el Emancipation Monument en Bridgetown en 1985 (interpretado por los barbadianos como la estatua de Bussa, el líder de la rebelión de 1816), el monumento Redemption Song en Jamaica, del 2003 (Modest, 2011), el monumento Spirit of Freedom, una estatua de la rebelde Sally Basset, en Hamilton, Bermuda, del 2009 (Swan, 2011) y la ruta conmemorativa Freedom footprints: the Barbados story, inaugurada en 2011 (Best, 2016). Sorprendentemente, el número de museos dedicados a la historia de la esclavitud es muy reducido (Pompey Museum of Slavery and Emancipation en Vendue House, Nassau). Aun así, es común que en museos de historia de cada isla haya una o varias salas sobre el tema: la Social History Gallery en el Barbados Museum and Historical Society (St. Michael) o la Slavery, Emancipation, and Plantation Life Collection en el National Museum Jamaica (Kingston). En el Caribe inglés también hay lugares turísticos en los que se niega o trivializa el pasado esclavista como el Sunbury Plantation House, en Barbados, donde en 1832 fueron explotados 224 esclavizados, pero que hoy alberga un restaurante de lujo ${ }^{55}$.

\section{Conclusión: los sitios de memoria en Cuba y otras regiones caribeñas}

Resulta que en las islas antillanas, independientemente de su antigua pertenencia a diferentes potencias coloniales y de su estatus político actual, coexiste una memoria de los esclavizados como víctimas, trabajadores y rebeldes, con una visión romántica del siglo XIX, lujoso y representado a través de antiguas casas señoriales, que minimiza el rol de los esclavizados en la construcción de esta belleza. La relación entre ambas presentaciones, entre otros factores, depende de la conciencia histórico-política de los afrocaribeños. ¿Han desarrollado una identidad como descendientes de esclavizados rebeldes o perciben su ascendencia como algo de lo que avergonzarse? ¿Se enorgullecen de sus raíces africanas o aspiran a igualarse con los blancos o europeos? Las memorias públicas de la esclavitud también dependen de las posibilidades de los afrocaribeños de influir en las políticas de/hacia el pasado. Estas oportunidades son mayores en las islas independientes democráticas y son menores en Cuba, una dictadura gobernada por una mayoría blanca (en comparación con otras islas, donde la mayoría de la población es afrodescendiente, con diferentes porcentajes de población asiática). En un punto intermedio, se encuentra la colonialcratie (expresión martinicana que hace referencia a la "democracia colonial" reinante) de los departamentos ultramarinos franceses, donde hay cierta participación democrática que está contrariada por el poder político y económico de los descendientes de los esclavistas (más relevante en Martinica que en Guadalupe y Guyana).

En las islas independientes, la minoría blanca todavía posee plantaciones que puede convertir en sitios de memoria donde se niega el pasado esclavista Los gobiernos lo aceptan porque la plantación, desde un punto de vista romántico, atrae a turistas y genera

\footnotetext{
${ }^{54}$ Visitas de ambos museos 20.5.2012.

${ }^{55}$ Database Legacies of British Slave-ownership, Sunbury, Barbados, St. Philip, https://www.ucl.ac.uk/lbs/estate/view/694, Sunbury Plantation House, https://www.facebook.com/Sunbury-Plantation-House-191138547587845/, 7.6.2020.
} 
ingresos. También la Cuba socialista promueve una imagen romántica de la plantación de cara al turismo, a la vez que en los museos estatales se aborda el tema de la esclavitud y la rebeldía esclava, aunque de manera insuficiente y sin incluir adecuadamente las voces de los esclavizados. Esta crítica no pretende dejar de lado el hecho de que todos los museos cubanos representan la esclavitud de forma más adecuada que los museos españoles, en los que en algunos únicamente hay una vitrina sobre el tema. En Cuba se permiten los lugares de memoria "desde abajo", ocupándose de su mantenimiento los descendientes de los esclavizados, en sitios alejados de las grandes ciudades y de las rutas turísticas. En las islas capitalistas, sin existir ninguna prohibición, depende de las posibilidades de los descendientes de los esclavizados crear sus propios sitios de contramemorias, homenajeando a sus ancestros desde su situación económica individual y la del municipio. Así, existen por lo menos algunos lugares que representan estas contramemorias.

\section{Referencias}

Augeron, M. y Caudron, O. (2012). La Rochelle, l’Aunis et la Saintonge face à la traite, à l'esclavage et à leurs abolitions. Un état des lieux. En M. Augeron y O. Caudron. (Eds.), La Rochelle, l'Aunis et la Saintonge face à l'esclavage (pp. 7-28). París: Les Indes Savantes.

Bahamonde, Á. y Cayuela, J. (1992). Hacer las Américas: las élites españolas en el siglo XIX. Madrid: Alianza.

Barcia, M.C. (2003). La otra familia: parientes, redes y descendencia de los esclavos en Cuba. La Habana: Casa de las Américas.

Barcia Zequeira, M. C. Ed. (2017). Una sociedad distinta: espacios del comercio negrero en el occidente de Cuba (1836-1866). La Habana: editora UH.

Beauvois, F. (2010). Monnayer l'incalculable? L'indemnité de Saint-Domingue, entre approximations et bricolage, Revue historique, 655 (3), 609-636.

Beckert, S. (2014). Empire of Cotton: a Global History. Nueva York: Knopf.

Belmonte Postigo, J. L. (2011). Ser esclavo en Santiago de Cuba. Espacios de poder y negociación en un contexto de expansión y crisis, 1780-1803. Madrid: Doce Calles.

Benjamin, R. (2012). Museums and Sensitive Histories: The International Slavery Museum. En A.L. Araujo. (Ed.). Politics of Memory: Making Slavery Visible in the Public Space (pp. 178-196). Nueva York: Routledge.

Bergad, L.W. (2007), The Comparative Histories of Slavery in Brazil, Cuba, and the United States. Cambridge: Cambridge Univ. Press.

Best, M. (2016). 'Freedom footprints: the Barbados story' - a slavery heritage trail. Journal of Heritage Tourism, 12 (5), 1-15, DOI: 10.1080/1743873X.2016.1255220

Bilé, S., Roman, A. y Sainte-Rose, D. (2011). Paroles d'esclavage. Les derniers témoignages. Saint-Malo: Galodé.

Borucki, A., Eltis, D. y Wheat, D. (2015), Atlantic History and the Slave Trade to Spanish America, The American Historical Review, 120 (2), 433-461. DOI: 10.1093/ahr/120.2.433

Burns, A.A. (2013), From Storefront to Monument: Tracing the Public History of the Black Museum Movement. Amherst: University of Massachusetts Press.

Castro Fernández, S. (2002). La masacre de los Independientes de Color en 1912. La Habana: Ciencias Sociales. 
Childs, M. (2006). The 1812 Aponte Rebellion in Cuba and the Struggle against Atlantic Slavery. Chapel Hill: Univ. of North Carolina Press.

Chivallon, C. (2012). L'esclavage, du souvenir á la mémoire, Contribution à une anthropologie de la Caraïbe. Paris: Karthala.

Chivallon, C. (2006). Rendre visible l'esclavage. Muséographie et hiatus de la mémoire aux Antilles françaises. L'Homme (180), 7-42. DOI: 10.4000/lhomme.24706

Coquery-Vidrovitch, C. (2009). Enjeux politiques de l'histoire coloniale, Paris: Agone.

Cozar Navarro, M.C. y Rodrigo y Alharilla, M. (Eds.) (2018). Cádiz y el tráfico de esclavos: de la legalidad a la clandestinidad. Madrid: Silex.

Cummins, A. (Ed.) (2013). Plantation to Nation. Caribbean Museums and National Identity. Champaign, Illinois: Common Ground Publishing.

Díaz Soler, L.M. (1970). Historia de la esclavitud negra en Puerto Rico. San Juan: Universidad de Puerto Rico.

Dinter, S. (2018). Die Macht der historischen Handlung, Sklaverei und Emanzipation in der britischen und französischen Erinnerungskultur seit Ende der 1990er Jahre. Bielefeld: transcript.

Dorigny, M. (2018). Arts \& Lettres contre l'esclavage. Paris: Cercle d'art.

Dorigny, M. y Zins, M.J. (Eds.) (2009). Les traites négrières coloniales. Histoire d'un crime, Paris: Cercle d'art.

Draper, N. (2010). The Price of Emancipation. Slave-Ownership, Compensation and British Society at the End of Slavery. Cambridge: Cambridge Univ. Press.

Eichstedt, J. y Small, S. (2002). Representations of Slavery. Race and Ideology in Plantation Museums. Washington: Smithsonian Institution.

Eltis, G. y Felipe-González, J. (2020). Rise and Fall of the Cuban Slave Trade. New Data, New Paradigms. En A, Borucki, D. Eltis, y D. Wheat, (eds.). From the Galleons to the Highlands. Slave Trade Routes in the Spanish Americas (pp. 201-222). Albuquerque: University of New Mexico Press.

Ernatus, C. (2009). L'indemnité coloniale de 1849, logique de solidarité ou logique coloniale?, Bulletin de la Société d'Histoire de la Guadeloupe, 152, 61-77. DOI 10.7202/1036869ar

Fondation pour la Mémoire de 1'Esclavage (2020). L'esclavage dans les manuels et les programmes scolaires: 7 Propositions. Les Notes de la FME, 1.

Ferrer, A. (1999). Insurgent Cuba, Race, Nation and Revolution, 1868-1898. Chapel Hill: Univ. of North Carolina Press.

Finch Aisha, K. (2015). Rethinking Slave Rebellion in Cuba. La Escalera and the Insurgencies of 1841-1844, Chapel Hill: University of North Carolina Press.

Fradera. J. M. (1984). La participació catalana en el tràfic d'esclaus (1789-1845), Recerques: historia/ economía/ cultura, 16, 119-139.

Frith, N. y Hodgson, K. (Eds.) (2015). At the Limits of Memory: Legacies of Slavery in the Francophone World. Liverpool: Liverpool Univ. Press.

Fuente, A. (2001). A Nation for All: Race, Inequality, and Politics in Twentieth-Century Cuba. Chapel Hill: Univ. of North Carolina Press.

Fuente, A. (2008). The New Afro-Cuban Cultural Movement and the Debate on Race in Contemporary Cuba, Journal of Latin American Studies, 40, 697-720. DOI:10.1017/S0022216X08004720

Gallas, K.L. y DeWolf Perry, J. (2015). Interpreting Slavery at Museums and Historic Sites. Lanham: Rowman \& Littlefield.

García Rodríguez, G. (1996). La esclavitud desde la esclavitud: la visión de los siervos. México: Centro de Investigacíon Científica "Ing. Jorge L. Tamayo". 
Gueye, A. (2011). Memory at Issue: On Slavery and the Slave Trade among Black French, Canadian Journal of African Studies / Revue canadienne des études africaines, 45(1), 77-107.

Guzmán Ralat, O., Berenguer, E. y Laviña, J. (2018). Barcelona, Llegats de l'esclavitud i l'abolicionisme. Barcelona: CCOO.

Hevia Lanier, O. (2011). Reconstruyendo la historia de la exesclava Belén Álvarez. En D. Rubiera Castillo, y I. M. Martiatu Terry. (eds.). Afrocubanas: Historia, pensamiento y prácticas culturales (pp. 30-53). La Habana: Ciencias Sociales.

Hourcade, R. (2014). Les ports négriers face à leur histoire: politique de la mémoire à Nantes. Bordeaux et Liverpool. Paris: Dalloz.

Katzew, I. (2004). Casta Painting: Images of Race in Eighteenth-Century Mexico, New Haven: Yale University Press.

Kowaleski-Wallace, E. (2006). The British Slave Trade and Public Memory. Nueva York: Columbia University Press.

L'inauguration du Mémorial ACTe, entre symboles et messages forts (2015.10.5). $\begin{array}{llll}\text { Recuperado el } & \text { 7.6.2020 }\end{array}$ https://la1ere.francetvinfo.fr/guadeloupe/2015/05/10/l-inauguration-dumemorial-acte-entre-symboles-et-messages-forts-254679.html,.

Lara, O. (2005). La liberté assassinée: Guadeloupe, Guyane, Martinique et la Réunion en 1848-1856. Paris: L’Harmattan.

Laviña, J. y Ruiz-Penado, J. L (2006). Resistencias esclavas en las Américas, Madrid: Doce Calles.

Marrero Cruz, E. (2006). Julián de Zulueta y Amondo: Promotor del capitalismo en Cuba. La Habana: Unión.

Michel, J. (2015). Devenir descendant d'esclave. Enquête sur les régimes mémoriels. Rennes: Presses Univ.

Modest, W. (2011). Slavery and the (Symbolic) Politics of Memory in Jamaica: Rethinking the Bicentenary. En L. Smith, G. Cubitt, R. Wilson y Fouseki, K. (Eds.). Representing Enslavement and Abolition in Museums. Ambiguous Engagements (pp. 75-94). Nueva York: Routledge.

Morgado García, A. (2013). Una metropóli esclavista. El Cádiz de la modernidad, Granada: Universidad de Granada.

Morgan, K. (2007). Liverpool's Dominance in the British Slave Trade, 1740-1807, En D. Richardson, S. Schwarz y A. Tibbles. (Eds.). Liverpool and Transatlantic Slavery (pp. 14-42). Liverpool: Liverpool University Press.

Mosquera Rosero-Labbé, C. y Barcelos, L. (Eds.) (2007). Afro-reparaciones. Memorias de la Esclavitud y Justicia Reparativa para Negros, Afrocolombianos y Raizales. Bogotá: Univ. Nacional de Colombia.

Nerín, G. (2015). Traficants d'ànimes: els negrers espanyols a l'Àfrica, Barcelona: Editorial Pòrtic.

Nora, P. (1984-1992). Les lieux de mémoire [vols 1-3.3], Paris: Gallimard.

Oudin-Bastide, C. (2008). Des nègres et des juges: la scandaleuse affaire Spoutourne (1831-1848). Paris: Complexe.

Pago, G, (2006). 1848: chronique de l'abolition de l'esclavage. Fort-de-France: Desnel.

Paquet, M.-E. (2009). Regard sur l'économie martiniquaise. Essai, Fort-de-France: K. Éditions.

Perera Díaz, A. y Meriño Fuentes, M. A. (2015). Estrategias de libertad: un acercamiento a las acciones legales de los esclavos en Cuba (1762-1872), [2 vols]. La Habana: Ciencias Sociales. 
Pérez García, R. M. (2018). Los negocios de la esclavitud: tratantes y mercados de esclavos en el Atlántico Ibérico, siglos XV-XVIII. Sevilla 2018.

Piqueras, J. A. (2012). La esclavitud en las Españas. Un lazo transatlántico, Madrid: Catarata.

Rauhut, C. (2012). Santería und ihre Globalisierung in Kuba: Tradition und Innovation in einer afrokubanischen Religion. Würzburg: Ergon.

Régent, F., Gonfier, G. y Maillard, B. (Eds.) (2015). Libres et sans fers: paroles d'esclaves français; Guadeloupe, Île Bourbon (Réunion), Martinique. Paris: Fayard.

Reinhardt, C. (2006). Claims to Memory. Beyond Slavery and Emancipation in the French Caribbean. Nueva York: Bergahn Books.

Rice, A. (2010). Creating Memorials, Building Identities: the Politics of Memory in the Black Atlantic. Liverpool: Liverpool Univ. Press.

Roca Barea, M.E. (2016). Imperiofobia. Roma, Rusia, Estados Unidos y el imperio español, Madrid: 2016.

Rodrigo y Alharilla, M. (2018.11.9). La dimensió colonial de la Barcelona contemporànea. Recuperado el 29.5.2020 de https://conversacionsobrehistoria.info/2018/09/07/conferencia-la-dimensiocolonial-de-la-barcelona-contemporania.

Rodrigo y Alharilla, M. (2000). Los marqueses de Comillas, 1817-1925. Antonio y Claudio López. Madrid: LID.

Rodrigo y Alharilla, M. (2012). Barcelona, capital del retorn. En M. Rodrigo y Alharilla (Ed.), Les bases colonials de Barcelona, 1765-1968 (pp. 79-92). Barcelona: MUHBA 2012.

Rodrigo y Alharilla, M. (2015). From Periphery to Centre: Transatlantic Capital Flows, 1830-1890. En: Leonard, A. y Pretel, D. (Eds.), The Caribbean and the Atlantic World Economy. Circuits of Trade, Money and Knowledge, 1650-1914 (pp. 217237). Basingstoke: Palgrave Macmillan.

Rodrigo y Alharilla, M. (2017). Cuatro capitanes negreros catalanes en tiempos de la trata ilegal: José Carbó, Pedro Manegat, Gaspar Roig y Esteban Gatell, En M. Rodrigo y Alharilla y L. Chaviano Pérez. (Eds.). Negreros y esclavos. Barcelona y la esclavitud atlántica (siglo XVI-XIX) (pp. 101-130). Barcelona: Icaria.

Rodrigo y Alharilla, M. y Chaviano Pérez, L Eds. (2017). Negreros y esclavos. Barcelona y la esclavitud atlántica (siglo XVI-XIX), Barcelona: Icaria.

Rogers, D. (2015). Voix d'esclaves. Antilles, Guyane et Louisiane françaises, XVIII ${ }^{e}$ XIX $^{e}$ siècles. Paris: Karthala.

Romay, Z. (2015). Cepos de la memoria. Impronta de la esclavitud en el imaginario social de Cuba. Matanzas: Ed. Matanzas.

Romay, Z. (2012). Elogio a la altea o las paradojas de la racialidad. La Habana: Casa de las Américas.

Sánchez-Albornoz, N. (1994, 2. ed.). La población de América latina. Desde los tiempos precolombinos al año 2025, Madrid: Alianza Ed.

Santamaría García, A. (Ed.) (2019). Azúcar, patrimonio y paisaje en Cuba, La Habana: Colegio Univ. San Gerónimo, Madrid: CSIC.

Sat, B. (2020.31.5). Statues de Scholcher brisées en Martinique: réflexion avec deux spécialistes de l'esclavage. Recuperado el 7.6.2020 de https://la1ere.francetvinfo.fr/statues-schoelcher-brisees-martinique-reflexiondeux-specialistes-esclavage- 838076 . 
Schmidt, N. (2009). La France a-t-elle aboli l'esclavage? Guadeloupe - Martinique Guyane (1830-1935). Paris: Perrin.

Schmieder, U. (2017). Nach der Sklaverei - Martinique und Kuba im Vergleich, 2a. ed., Berlin: LIT.

Smith, L., Cubitt, G., Wilson, R. y Fouseki, Kalliopi (Eds.), Representing Enslavement and Abolition in Museums. Ambiguous Engagements, Nueva York: Routledge.

Solow, B. L. (1987). Capitalism and Slavery in the Exceedingly Long Run. The Journal of Interdisciplinary History, 17(4), 711-737.

Spalding, N. (2011). Learning to Remember Slavery: School Field Trips and the Representation of Difficult Histories in English Museums. Journal of Educational Media, Memory \& Society, 3(2), 155-172.

Straehle, E. (2019). Historia y leyenda de la Leyenda Negra: Reflexiones sobre Imperiofobia, de María Elvira Roca Barea, Nuestra Historia: revista de Historia de la FIM, 8, 113-137.

Stromberg Childers, K. (2016). Seeking Imperialism's Embrace. National Identity, Decolonization, and Assimilation in the French Caribbean. Oxford: Oxford University Press.

Swan, Q. (2011). Smoldering memories and Burning Questions. The Politics of Remembering Sally Bassett and Slavery in Bermuda. En A. L. Araujo (Ed.), Politics of Memory. Making Slavery Visible in the Public Space (pp. 71-105). Nueva York: Routledge.

Solà Parera, M. A. (2012). Els capitals americans i la industrialització en Barcelona al segle XIX. (2012). En: M. Rodrigo y Alharilla (Ed.), Les bases colonials de Barcelona, 1765-1968 (pp. 69-78). Barcelona: MUHBA.

Surwillo, L. (2014). Monsters by Trade: Slave Traffickers in Modern Spanish Literature and Culture. Stanford: Stanford Univ. Press.

Tibbles, A. (2018). Liverpool and the Slave Trade. Liverpool: Liverpool University Press.

Toasije, A. (2014). La memoria y el reconocimiento de la comunidad africana y africanodescendiente negra en España: el papel de la vanguardia panafricanista: Nómadas. Revista Crítica de Ciencias Sociales y Jurídicas. 28(4), 277-316.

Tomich, D. y Zeuske, M. (2008). Introduction, REVIEW, A Journal of the FERNAND BRAUDEL CENTER for the Study of Economies, Historical Systems, and Civilizations, $X X X I$ (2), 91-100.

United Nations Human Rights Council (2018.14.8) Informe del Grupo de Trabajo de Expertos sobre los Afrodescendientes acerca de su misión a España, a la Asamblea General de las Naciones Unidas. Recomendaciones $n^{\circ} 72$. A/HRC/39/69/ Add.2.

Wood, M. (2000). Blind Memory, Visual Representations of Slavery in England and America, 1780-1865. Manchester: Manchester Univ. Press.

Zanetti Lecuona. O. y García Álvarez, A. (1987). Caminos para el azúcar. La Habana: Ediciones Sociales.

Zeuske, M. (2017). Capitanes y comerciantes catalanes de esclavos, En M. Rodrigo y Alharilla y L. Chaviano Pérez. (Eds.). Negreros y esclavos. Barcelona y la esclavitud atlántica (siglo XVI-XIX) (pp. 63-100). Barcelona: Icaria.

Zeuske, M. (2004). Schwarze Karibik, Sklaven, Sklavereikultur und Emanzipation. Zürich: Rotpunktverlag. 